\title{
Design and Development of Biosensors for the Detection of Heavy Metal Toxicity
}

\author{
Graziella L. Turdean \\ Physical Chemistry Department, Babes-Bolyai, University of Cluj-Napoca, 11 Arany Janos Street, 400028 Cluj-Napoca, Romania \\ Correspondence should be addressed to Graziella L. Turdean, gturdean@chem.ubbcluj.ro
}

Received 28 February 2011; Accepted 23 March 2011

Academic Editor: Sibel A. Ozkan

Copyright (๑) 2011 Graziella L. Turdean. This is an open access article distributed under the Creative Commons Attribution License, which permits unrestricted use, distribution, and reproduction in any medium, provided the original work is properly cited.

\begin{abstract}
Many compounds (including heavy metals, HMs) used in different fields of industry and/or agriculture act as inhibitors of enzymes, which, as consequence, are unable to bind the substrate. Even if it is not so sensitive, the method for detecting heavy metal traces using biosensors has a dynamic trend and is largely applied for improving the "life quality", because of biosensor's sensitivity, selectivity, and simplicity. In the last years, they also become more and more a synergetic combination between biotechnology and microelectronics. Dedicated biosensors were developed for offline and online analysis, and also, their extent and diversity could be called a real "biosensor revolution". A panel of examples of biosensors: enzyme-, DNA-, imuno-, whole-cell-based biosensors were systematised depending on the reaction type, transduction signal, or analytical performances. The mechanism of enzyme-based biosensor and the kinetic of detection process are described and compared. In this context, is explainable why bioelectronics, nanotechnology, miniaturization, and bioengineering will compete for developing sensitive and selective biosensors able to determine multiple analytes simultaneously and/or integrated in wireless communications systems.
\end{abstract}

\section{Introduction}

1.1. About Heavy Metals. Heavy metals (HMs) and their ions are ubiquitous and by definition are metals having atomic weights between 63.5 and $200.6 \mathrm{~g} \mathrm{~mol}^{-1}$ and a specific gravity greater than $5 \mathrm{~g} \mathrm{~cm}^{-3}$ [1]. Living organisms require small doses of some essential heavy metals, including cobalt, copper, iron, manganese, molybdenum, vanadium, strontium, and zinc. However, in the case of essential metals and very toxic metals, excessive levels and, respectively, even small doses, influence both the ecosystem and human health [2]. Nonessential heavy metals which affect the surface water systems are cadmium, chromium, mercury, lead, arsenic, and antimony.

Because HMs are relatively abundant in the Earth's crust and are often used in industrial processes and agriculture, consequently they become toxic to humans. These can make important alterations to the biochemical cycles of life. Human activities are adapted and interfered with natural cycles and produced a release to the aquatic and terrestrial systems. The HMs are transported by runoff water and contaminate water sources downstream from the industrial site. For life, all living (micro)organisms, plants, and animals depend on water, but because heavy metals can bind to the surface of microorganisms, they may be transported inside the cell. There, the HMs can be chemically changed using chemical reactions similarly with those for digesting food $[1,2]$.

The determination of trace levels (subpart per billion, $\mathrm{ppb}$ ) of toxic HMs in complex matrices like biological material (serum and cytoplasm of cells) for clinical medicine/toxicology and animal husbandry, natural waters (ocean, sea, rivers), wastewater (from mining, metal processing, tanneries, pharmaceuticals, pesticides, organic chemicals, rubber and plastics, lumber and wood products, etc.), soil and air for chemical oceanography or for environmental monitoring (wastewater treatment or monitoring), for industrial process monitoring has become very important, because these media are vulnerable to this class of pollutants $[1,3-5]$. 
Powerful analytical methods/techniques including atomic absorption and emission spectroscopy, inductively coupled plasma mass spectroscopy, and their combination with chromatographic techniques are widely used and are commercially available. These techniques exhibit high sensitivity, selectivity, reliability, and accuracy, but require sophisticated instrumentation inadequate for use outside the laboratory, skilled personel, complicated sample collection, pretreatment (pre-concentration), and a long measuring period [ 3 , $6,7]$.

Consequently, with the comparable sensitivity and selectivity, the electrochemical methods such as ion-selective electrodes, biosensors, polarography, and other voltammetric techniques are also extensively used as attractive choice to the classical methods, due to their less complex instrumentation and shorter measuring period [7]. Also, simple, inexpensive, and portable instruments are attractive and desirable for real-time sampling/measuring and online and continuous analysis/monitoring/control of natural samples [3].

1.2. What Is a Biosensor?. According to the International Union of Pure and Applied Chemistry (IUPAC) (namely Physical Chemistry and Analytical Chemistry Divisions) a biosensor is defined as "a self-contained integrated device that is capable of providing specific quantitative or semi-quantitative analytical information using a biological recognition element (biochemical receptor) which is in direct spatial contact with a transduction element" $[8,9]$. A typical biosensor construct has three main features: a recognition element (enzyme, antibody, DNA, etc.), a signal transducing structure (electrical, optical, or thermal), and an amplification/processing element (see Figure 1), same models including also, a permselective membrane which controls transport of analyte to the bioreceptor [10].

As summarized in Table 1, various transduction mechanisms can be used: electrochemical, electrical, optical, thermal, and piezoelectric $[8,11]$. Most commonly, in a biosensor, a biorecognition phase (e.g., enzyme, antibody, receptor, and single-stranded DNA) interacts with the analyte to produce a signal, which may be due to (i) a change in proton concentration, (ii) a release or uptake of gases such as ammonia or oxygen, (iii) a release or uptake of electrons, (iv) a light emission, absorption, or reflectance, (v) a heat emission, or (vi) a mass change, and so forth. The function of the transducer is to convert the signal into an appropriate measurable response (e.g., current, potential or temperature change). Through signal processing, this interaction is converted into digital values that relate to the build-up of concentration/activity of the analyte in the environs of the device, which in turn relates to the ambient levels in the bulk investigated sample. A biosensor is not necessarily an individual entity, but is considered as part of a general designed instrumentation [8].

\section{Enzyme-Based Biosensor}

Adsorption, covalent binding to solid surfaces and supported films, entrapment in polymer hydrogels and
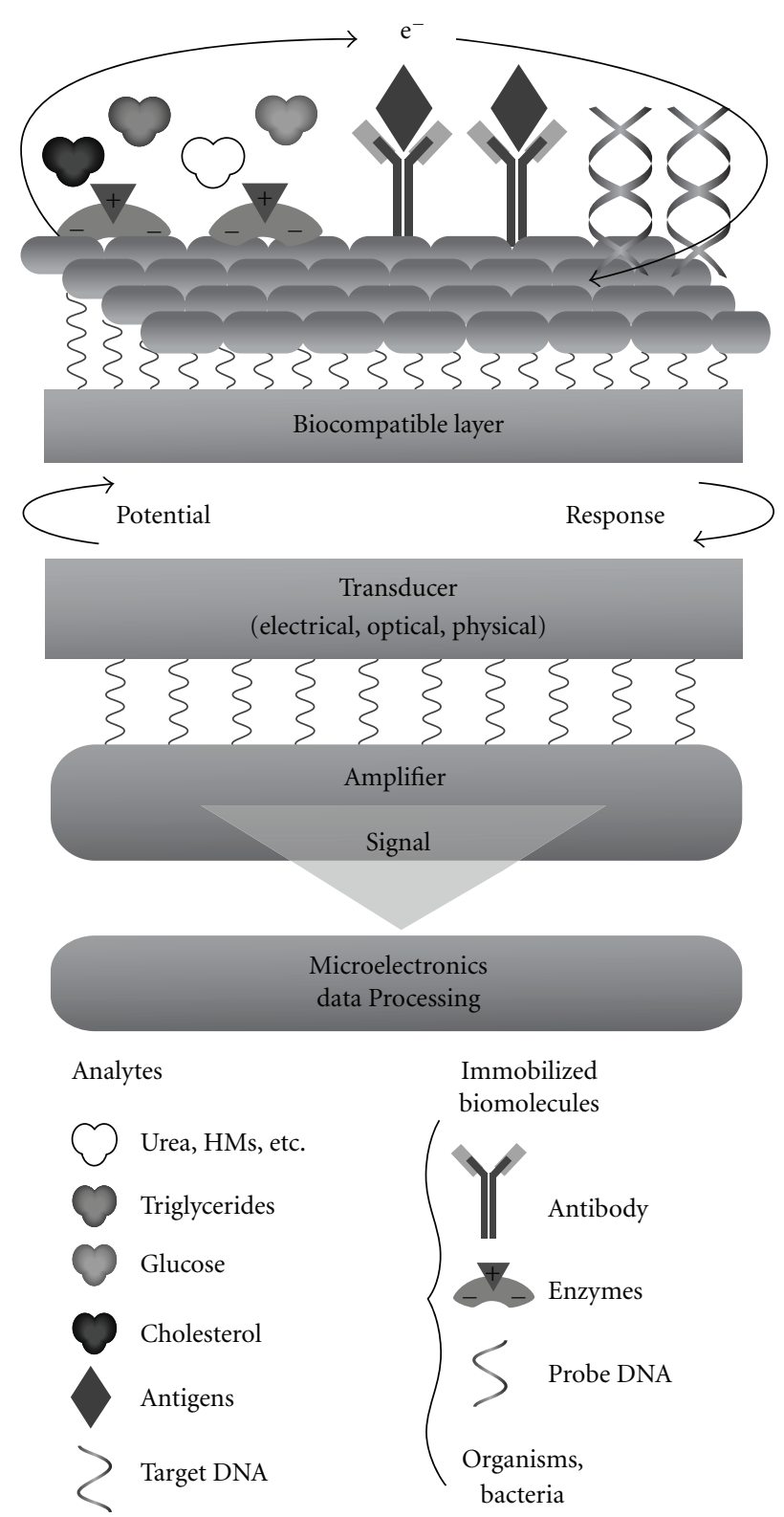

FIGURE 1: Schematic principle of operation of a biosensor.

microencapsulation have been used for a long period to immobilize enzymes [12].

The application of immobilized enzymes has several advantages in comparison with free enzymes $[13,14]$ :

(i) thousands times lower consumption of immobilized enzyme;

(ii) reduction of interferences by the differential mode of operation;

(iii) unnecessary preincubation;

(iv) rapid analysis procedure, less than $5 \mathrm{~min}$;

(v) in the case of reversible inhibition, sometimes the reactivation of enzyme activity is not necessary.

Biosensors have been used for indirect monitoring of organic (e.g., pesticides) or inorganic substances (e.g., heavy 
TABle 1: Principal transduction systems used in biosensors.

\begin{tabular}{ll}
\hline Transduction system & Measurement/parameters \\
\hline \multirow{2}{*}{ Electrochemical } & Amperometry/current \\
Electrical & Potentiometry/voltage at zero current \\
& Conductometry/conductance \\
Optical & Fotometry/luminescence \\
& Fotometry/fluorescence \\
Thermal & Refractometry/refractive index \\
Piezoelectric & Calorimetry/temperature \\
& Mass-quartz crystal microbalances/mass \\
& Mass-surface acoustic waves/velocity and so forth. \\
\hline
\end{tabular}

metals) which inhibit its biocatalytic properties. The problem with biosensors based in enzymatic inhibition is that only a few enzymes are sensitive to heavy metals [12].

Generally, for a bioelectrocatalytical scheme the following reactions it can be written as follows:

$$
\begin{gathered}
\mathrm{S}+\mathrm{E}_{\mathrm{ox}} \stackrel{K_{\mathrm{s}}}{\longrightarrow}\left[\mathrm{S}-\mathrm{E}_{\mathrm{ox}}\right] \stackrel{k_{\mathrm{cat}}}{\longrightarrow} \mathrm{P}+\mathrm{E}_{\mathrm{red}}, \\
\mathrm{M}_{\mathrm{ox}}+\mathrm{E}_{\mathrm{red}} \stackrel{K_{M}}{\longleftrightarrow}\left[\mathrm{M}-\mathrm{E}_{\mathrm{red}}\right] \stackrel{k_{\mathrm{cat}}}{\longrightarrow} \mathrm{M}_{\mathrm{red}}+\mathrm{E}_{\mathrm{ox}}, \\
\mathrm{M}_{\mathrm{red}} \longrightarrow \mathrm{M}_{\mathrm{ox}}+e^{-},
\end{gathered}
$$

where $S$ is a substrate; $P$ is a product; $E$ is a enzyme; $M_{o x}$, $\mathrm{M}_{\text {red }}$ are the oxidized and reduced forms of a redox mediator molecules.

The "ping-pong" mechanism is proposed for the enzyme reaction described by a reaction rate $\left(v_{S}\right)$, which at steady state is given by $(4)$. The measured current $\left(I_{\text {app }}\right)$ reflects $v_{S}$, as expressed by the approximate equation [15]:

$$
\begin{aligned}
v_{s} & =\frac{k_{\mathrm{cat}}[\mathrm{E}]}{1+\left(K_{S} /[\mathrm{S}]\right)+\left(K_{M} / \mathrm{M}_{\mathrm{ox}}\right)}, \\
I_{\mathrm{app}} & =F A[\mathrm{M}] \sqrt{\frac{2 n_{S} n_{\mathrm{M}} D_{\mathrm{M}} k_{\mathrm{cat}}[\mathrm{E}]}{2 K_{M}+[\mathrm{M}]}},
\end{aligned}
$$

where $k_{\text {cat }}=$ catalytic constant; $K_{S}$ is Michaelis constant for S; $K_{M}$ is Michaelis constant for $\mathrm{M}_{\mathrm{ox}}$; E is enzyme concentration; $\mathrm{S}$ is substrate concentration; $\mathrm{M}_{\mathrm{Ox}}$ is mediator concentration; $F$ is Faraday's constant; $A$ is electrode surface area; $M$ is bulk concentration of mediator $\mathrm{M} ; D_{\mathrm{M}}$ is diffusion coefficient of $\mathrm{M} ; n_{\mathrm{S}}$ and $n_{\mathrm{M}}$ are the number of electrons involved in (1)-(3), respectively.

2.1. Enzyme Inhibitor System. The long-term function of enzyme-based biosensors may be severely limited by the powerful of inhibitors which is measured. Because the enzyme-inhibitor reaction is habitually complicated, the inhibition of the enzyme can be either reversible or an irreversible inactivation.

Sometimes the effect of an inhibitor can be reversed by decreasing the concentration of inhibitor (e.g., by dilution or dialysis). It is the case of the reversible inhibition. Once inhibition has occurred and there is no reversal of inhibition with decreasing the inhibitor concentration, the inhibition is called irreversible. The difference between reversible and irreversible inhibition is not absolute and is difficult to do, if the inhibitor binds very strongly to the enzyme and if it is released very slowly. Reversible inhibitors that work in a way that is difficult to distinguish from irreversible inhibition are called tight-binding inhibitors [16].

2.1.1. Reversible Inhibition. Reversible inhibitors are molecules that bind reversibly to enzymes with rapid association by noncovalent interactions and rapid dissociation rates. This chemical equilibrium between the enzyme and the inhibitor can be displaced in favour of the enzyme and so the activity of the enzyme can be regained, by the removal of the inhibitor by dialysis, gel filtration, and so forth. The removal of the inhibitor restores the enzyme activity to its original value.

The inhibition process of the immobilised enzyme can be described by the following generally kinetic scheme $[11,16-$ 18]:

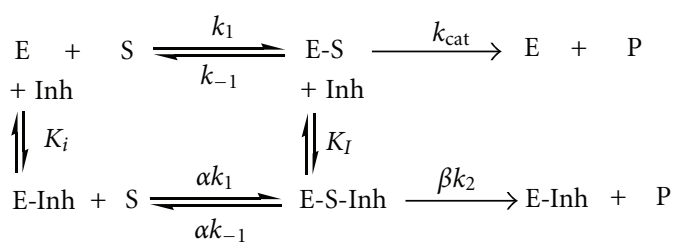

where: $\mathrm{E}$ is immobilised enzyme; $\mathrm{S}$ is free substrate; $\mathrm{P}$ is product; E-S is enzyme-substrate complex; E-Inh is enzymeinhibitor complex; E-S-Inh is ternary complex containing enzyme-substrate inhibitor; $K_{I}$ and $K_{i}$ are equilibrium dissociation constants of the E-S-Inh complex and the E-Inh complex, respectively.

In function of the binding site, inhibitors can be: competitive, uncompetitive, noncompetitive and mixed, and their effects on the kinetic parameters $\left(K_{M}\right.$ and $\left.v_{\max }\right)$ are resumed in Table $2[19,20]$.

From the general scheme 6 the value of equilibrium dissociation constants $\left(K_{I}, K_{i}\right)$ could be calculated from 
TABLE 2: Type of inhibitors.

\begin{tabular}{|c|c|c|}
\hline Inhibitor type & Binding site on enzyme & Kinetic effect \\
\hline $\begin{array}{l}\text { Competitive } \\
\text { inhibitor }\end{array}$ & $\begin{array}{l}\text { An inhibitor that is structurally similar to the } \\
\text { substrate cannot undergo the catalytic step, so it } \\
\text { wastes the enzyme's time by preventing } S \text { binding, } \\
\text { that is, inhibitor competes with substrate for the } \\
\text { enzyme-substrate binding site in a dynamic } \\
\text { equilibrium process, thus increasing } K_{M} \text { for } \\
\text { substrate. } \\
\text { Inhibition is reversible using high concentrations } \\
\text { of substrate. }\end{array}$ & $v_{\max }$ is unchanged; $K_{M}$ is increased. \\
\hline $\begin{array}{l}\text { Uncompetitive } \\
\text { inhibitor }\end{array}$ & $\begin{array}{l}\text { Binds only to ES complexes at locations other } \\
\text { than the catalytic site. Substrate binding modifies } \\
\text { enzyme structure, making inhibitor-binding site } \\
\text { available. Inhibition cannot be reversed by } \\
\text { substrate. }\end{array}$ & $\begin{array}{l}v_{\max } \text { and } K_{M} \text { decreased with the same } \\
\text { factor. }\end{array}$ \\
\hline $\begin{array}{l}\text { Noncompetitive } \\
\text { inhibitor }\end{array}$ & $\begin{array}{l}\text { If the inhibitor is not only bound to the E, but } \\
\text { also to the E-S complex, at a remote site other } \\
\text { than at the catalytic site of the enzyme, thus the } \\
\text { active centre is usually deformed and its function } \\
\text { is thus impaired, affecting } k_{\text {cat }} \text {. In this case the } \\
\text { substrate and the inhibitor do not compete with } \\
\text { each other. Substrate binding is unaltered, but ESI } \\
\text { complex cannot form products. Inhibition cannot } \\
\text { be reversed by substrate. }\end{array}$ & $\begin{array}{l}K_{M} \text { appears unaltered; } v_{\max } \text { is decreased } \\
\text { proportionately to inhibitor concentra- } \\
\text { tion. }\end{array}$ \\
\hline Mixed inhibitor & $\begin{array}{l}\text { AS the noncompetitive, this inhibitor binds at a } \\
\text { site other than the active site (E or ES) and causes } \\
\text { changes in the overall 3D shape of the enzyme } \\
\text { that leads to a decrease in activity. The inhibitor } \\
\text { binds to E and ES with different affinity ( } K_{i} \text { not } \\
\left.\text { equal to } K_{I}\right) \text {. Mixed inhibition cannot be } \\
\text { overcome by high substrate concentration. }\end{array}$ & $\begin{array}{l}v_{\max } \text { decrease and } K_{M} \text { either increase or } \\
\text { decrease. }\end{array}$ \\
\hline
\end{tabular}

the slope and intercept of the linear plot $1 / \mathrm{I}$ versus $1 /[\mathrm{S}]$ according to (7) $[12,21]$ :

$$
\frac{1}{I}=\left(1+\frac{[\operatorname{Inh}]}{K_{i}}\right) \frac{K_{M}}{I_{\max }[S]}+\left(1+\frac{[\operatorname{Inh}]}{K_{I}}\right) \frac{1}{I_{\max }} .
$$

2.1.2. Irreversible Inactivation. The term irreversible inhibitor means that the decomposition of the enzyme-inhibitor complex results in the destruction of enzyme (e.g., its hydrolysis, oxidation, etc.) or modification of an essential aminoacid required for enzyme activity. Frequently, this is due to a covalent bond between the enzyme active site and the inhibitor. These inhibitors are designed to mimic the natural substrate in the recognition phase and to bind to the active site of the enzyme in a second step. Upon binding and some catalytic modification, a highly reactive inhibitor product is formed, that binds irreversibly and consequently inactivates the enzyme [19].

The kinetics of the inhibition depends strongly on the biosensor configuration. Thus, in the case of a thin enzymatic layer, the kinetics observed is similar to that of the enzyme in solution. Also, the inhibition of native enzymes is related directly to the incubation time [19]. An interesting case concerning the inhibition of peroxidise by HM was investigated [7]. The conclusion is that there exists an early phase of reversible inhibition ( $5 \mathrm{~s}$ ), followed by irreversible inhibition. As consequence, it is hard to accomplish the amperometric measurement of remaining activity $\left(v_{i}\right)$ so soon after a reversible inhibition. However, irreversible inhibition or inactivation has to be considered, when longer incubation times were used (1-8 min). Also, HM salts at high concentration $(>1 \mathrm{mM})$ inactivate all enzymes by coprecipitation, while lower concentrations affect only some enzyme activities by interaction with specific protein groups [22].

Knowing that the irreversible inactivation follows the reaction mechanism described by scheme (8) [22]

$$
\begin{aligned}
& \mathrm{E}+\mathrm{S} \underset{k_{-1}}{\mathrm{E}} \mathrm{E}-\mathrm{S} \stackrel{k_{\text {cat }}}{\longrightarrow} \mathrm{E}+\mathrm{P} \\
& +\mathrm{Inh} \\
& \prod_{K_{i}}^{\stackrel{k_{\text {inac }}}{\longrightarrow} \text { E-Inh' }}
\end{aligned}
$$

and supposing that the irreversible inactivation process was a first order versus enzyme concentration [E], according to the literature, the reaction rate is described by equation (9)

$$
\frac{\mathrm{d}[\mathrm{E}]}{\mathrm{dt}}=-k_{\mathrm{obs}}[\mathrm{E}]
$$


which become after variable separation:

$$
\frac{\mathrm{d}[\mathrm{E}]}{[\mathrm{E}]}=-k_{\mathrm{obs}} \mathrm{dt} .
$$

After integration

$$
\ln v_{i}=-k_{\mathrm{obs}} t+\text { const, }
$$

the linear dependence of $\ln v_{i}$ versus $t$ which can be plotted for each incubation time is obtained.

The experimental slope is

$$
k_{\mathrm{obs}}=\frac{k_{\mathrm{inac}}[\operatorname{Inh}]}{[\operatorname{Inh}]+K_{i}},
$$

where [Inh] is inactivator concentration, $K_{i}$ is equilibrium dissociation constant, and $k_{\text {inac }}$ is rate constant of inactivation.

(i) For $[$ Inh $] \ll K_{i}$, equation (12) became

$$
k_{\mathrm{obs}}=\frac{k_{\mathrm{inac}}[\operatorname{Inh}]}{K_{i}} .
$$

Thus the $1 / k_{\text {obs }}$ plotted against $1 /[$ Inh] is a straight line with the slope $K_{i} / k_{\text {inac }}$ [7], which permit also the determination of the detection limit and the efficiency of inactivation.

(ii) For [Inh] around $K_{i}, 1 / k_{\text {obs }}$ plotted versus $1 /[$ Inh] permitted the determination of $k_{\mathrm{i}}$ and $K_{\mathrm{i}}$ and calculation of $k_{i} / K_{i}[22]$.

Also, when the inhibition reaction 6 is reduced to scheme (8) (i.e., $K_{I} \rightarrow \infty, \alpha k_{1} \rightarrow \infty, k_{2} \rightarrow 0$ ) the inhibition constant $\left(K_{i}\right)$ value can be determined from the slope and intercept of the linear $1 / I$ versus $1 /[S]$ plot of the modified equation (7) $[12,21]$ :

$$
\frac{1}{I}=\left(1+\frac{[\operatorname{Inh}]}{K_{i}}\right) \frac{K_{M}}{I_{\max }[S]}+\frac{1}{I_{\max }}
$$

2.1.3. Degree of Inhibition. Irreversible inhibition is usually quantified in terms of the rate of inhibition. In order to investigate the heavy metals inhibition an experimental method is used consisting in recording the bioelectrode amperometric response to successive additions of substrate, before and after its incubation in an inhibitor solution, for a given period of time. Thus, the method allows to calculate the percent of inhibition (\% Inh), defined using the formula [23-28]:

$$
\% \operatorname{Inh}=\frac{I_{0}-I}{I_{0}} * 100,
$$

where $I_{0}$ is bioelectrode initial response when the inhibitor was absent; $I$ is bioelectrode response after incubation with the inhibitor.

Also, it was reported that the degree of inhibition depends on the concentration of the inhibitor and on the exposure time (at a defined $\mathrm{pH}$ value and at inhibitor concentration which is in excess with respect to enzyme)
$[29,30]$. There have been some initial efforts at the development and experimental verification of theoretical models for the inhibition of immobilized enzymes using biosensors. When diffusion phenomenon are taken into account, the model predicts that the percentage of enzyme inhibition (\% Inh), after exposure to an inhibitor, is linearly related to both the inhibitor concentration [Inh] and the square root of incubation time $\left(t^{1 / 2}\right)[19,31]$.

\subsection{Examples of Enzyme-Based Biosensors for Heavy Metal} Detection. For heavy metals detection, different enzymes such as acetylcholinesterase, alkaline phosphatase, urease, invertase, peroxidise, L-lactate dehydrogenase, tyrosinase, and nitrate reductase, have been used. The inhibition of the immobilized enzyme can be detected via electrochemical (amperometric, potentiometric, and conductometric) or optical measurements. The principle of detection is resumed in Table 3 and the analytical parameters of the enzyme-based biosensors are summarized in Table 4.

\section{DNA-Based Biosensor}

During last years, there has been a huge increase in the use of nucleic acids, as a way in the recognition and monitoring of many toxic compounds of analytical interest, because many of this molecules, and especially HMs, show a high affinity for DNA and they can interact with nucleic acids. The interaction between metal ions and DNA is important in living organisms, because it could have, either favourable, or adverse effects in life science reported to the damage, replication and transcription of DNA in vivo, mutation of gene, action mechanism of some synthetic chemical nucleases, and molecular analysis [57], which often lead to the change of the structure and function of genetic materials, by development of malignant tumours [58]. Thus, the ability to monitor and quantify the levels of HMs (such as $\mathrm{Pb}, \mathrm{Cd}$, and $\mathrm{Ni}$ ) that interact with DNA is widely studied [59], because these ions have been detected in different sources: foods, beverages, soil, plants, natural waters, and so forth. Also, the International Agency for Research on Cancer (IARC) lists some HMs (as $\mathrm{Pb}$ and $\mathrm{Cd}$ ) as possible human carcinogens, while the carcinogenic properties of $\mathrm{Ni}$ are related to tumour promotion [58].

Usually, for HMs studies, the DNA was native (from Calf Thymus, double-stranded DNA, ds-DNA) or denaturated (single-stranded DNA, ss-DNA) [59, 60]. The electrochemical techniques (chronopotentiometric or voltammetric methods), especially the pulse techniques, are appropriate for studying the biological systems, and also, for DNA heavy metal interactions, because they improve the selectivity and the signal-to-noise ratio, are fast, of low cost, and have high sensitivity $[57,58]$.

An electrochemical DNA biosensor is an integrated receptor-transducer device that uses DNA as a biomolecular recognition element to measure specific binding processes with DNA, through electrochemical (especially carbon electrodes) transduction [57]. As for other biosensors, the most important factor for the construction of efficient DNA-based 
TABle 3: Principle of detection using enzyme-based biosensors.

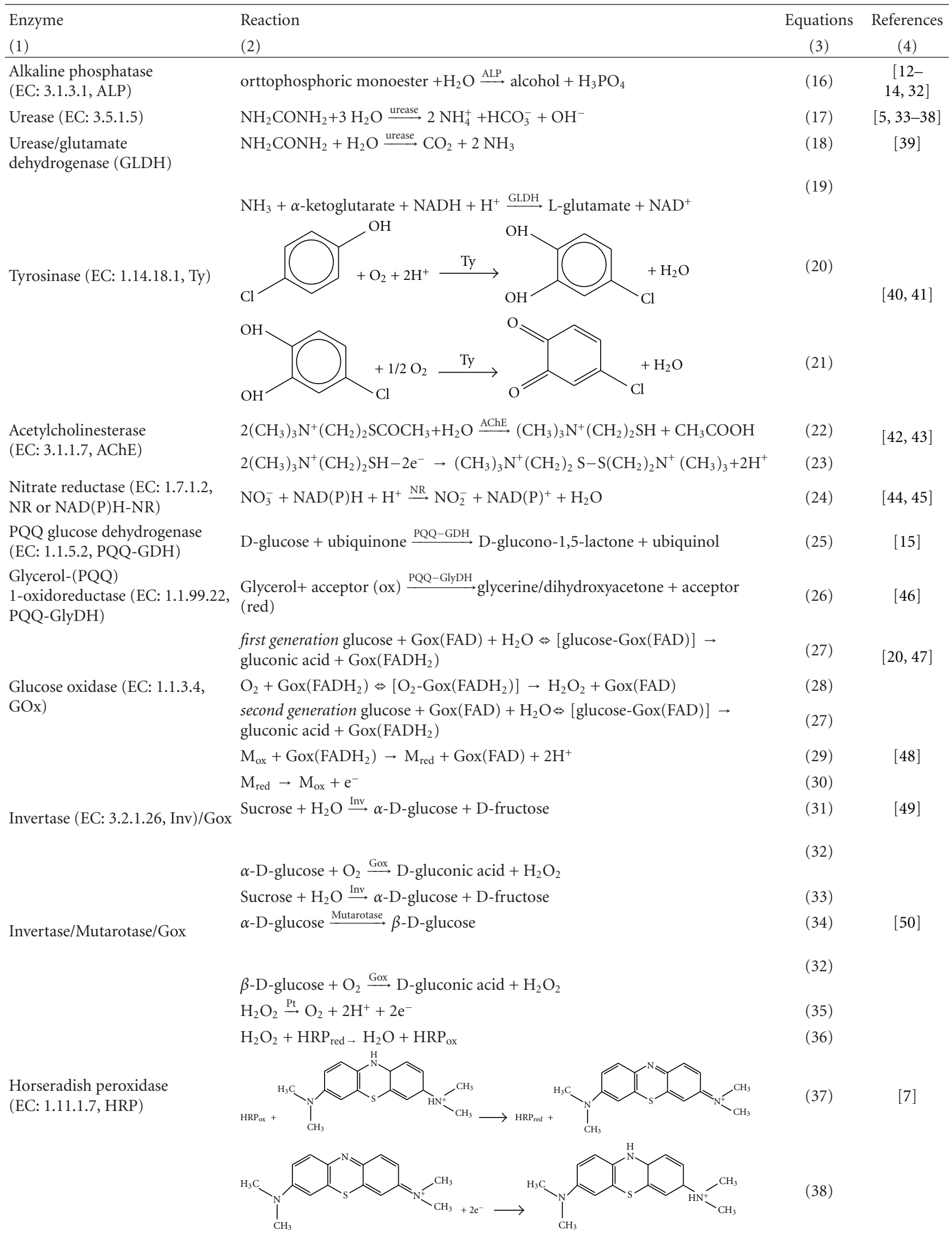


TABle 3: Continued.

\begin{tabular}{llr}
\hline $\begin{array}{l}\text { Enzyme } \\
(1)\end{array}$ & $\begin{array}{l}\text { Reaction } \\
(2)\end{array}$ & $\begin{array}{c}\text { Equations } \\
\text { References }\end{array}$ \\
\hline $\begin{array}{l}\text { L-lactate dehydrogenase (EC: } \\
\begin{array}{l}1.1 .1 .27, \mathrm{LDH}) / \mathrm{L}-\text { lactate oxidase } \\
(\mathrm{EC}: 1.13 .12 .4, \mathrm{LOD})\end{array}\end{array}$ & $\mathrm{NADH}+\mathrm{H}^{+}+$pyruvate $\stackrel{\text { LDH }}{\longrightarrow}$ L-lactate $+\mathrm{NAD}^{+}$ & $(3)$
\end{tabular}

TABLE 4: Principle characteristics of enzyme biosensors for heavy metal detection.

\begin{tabular}{|c|c|c|c|}
\hline Enzyme & Detection; working electrode; applied potential & Limit of detection & References \\
\hline AChE & Amperometry; G/AChE; $0.80 \mathrm{~V}$ versus SCE & $10^{-10} \mathrm{M} \mathrm{Hg}^{2+}$ & {$[43]$} \\
\hline ALP & Conductometry; Au/ALP-GA-BSA-glycerol;- - & $\begin{array}{l}0.5 \mathrm{ppm} \mathrm{Cd}^{2+}, 2 \mathrm{ppm} \mathrm{Zn}^{2+} \\
2 \mathrm{ppm} \mathrm{Co}^{2+}, 5 \mathrm{ppm} \mathrm{Ni}^{2+} \\
40{\mathrm{ppm} \mathrm{Pb}^{2+}}^{2}\end{array}$ & {$[13]$} \\
\hline ALP & Amperometry; SPE/ALP-chitosan; +0.6 versus $\mathrm{Ag} / \mathrm{AgCl}$ & $\begin{array}{l}\mathrm{mg} / \mathrm{L} \mathrm{Hg}^{2+}, \mathrm{Cd}^{2+}, \mathrm{Ag}^{+} \\
\mathrm{Zn}^{2+}, \mathrm{Cu}^{2+}\end{array}$ & {$[51]$} \\
\hline ALP & Fluorescence;- & $10.1 \mu \mathrm{M} \mathrm{Ag}^{+}$ & {$[12]$} \\
\hline ALP & Chemiluminescence;- & $0.36 \mathrm{ppb} \mathrm{Zn^{2+ }}$ & {$[52]$} \\
\hline HRP & Amperometry; GCE/MB-HRP-GdA & $\begin{array}{l}0.1 \mathrm{ng} / \mathrm{mL} \mathrm{HgCl}_{2} \\
0.2 \mathrm{ng} / \mathrm{mL} \mathrm{Hg}_{2}\left(\mathrm{NO}_{3}\right)_{2}\end{array}$ & {$[7]$} \\
\hline Gox & Amperometry; Pt/PA/Fc/GA/GOx; +0.7 V versus SCE & $0.49 \mu \mathrm{g} / \mathrm{L} \mathrm{Hg}^{2+}$ & {$[48]$} \\
\hline Gox & Amperometry; Pt/PPD/GOx; +0.7 V versus SCE & $\begin{array}{l}2.5 \mu \mathrm{M} \mathrm{Hg}^{2+}, 0.05 \mu \mathrm{M} \mathrm{Ag}^{+} \\
5.0 \mu \mathrm{M} \mathrm{Cu}^{2+}, 5.0 \mu \mathrm{M} \mathrm{Cd}^{2+} \\
12.0 \mu \mathrm{M} \mathrm{Fe}^{3+}, 8.0 \mu \mathrm{M} \mathrm{Co}^{2+} \\
4.8 \mu \mathrm{M} \mathrm{Ni}^{2+}, 48 \mu \mathrm{MrO}_{4}^{2-}\end{array}$ & {$[20,47]$} \\
\hline Inv Gox & $\begin{array}{l}\text { Amperometry; Pt/Inv-Gox-agarose-guar gum; +0.35 } \\
\text { versus Ag/AgCl }\end{array}$ & $\begin{array}{l}5^{*} 10^{-10} \mathrm{M} \mathrm{Hg}^{2+}, 3^{*} 10^{-8} \mathrm{M} \\
\mathrm{Pb}^{2+}, 5^{*} 10^{-8} \mathrm{M} \mathrm{Ag}^{+}, 2.5^{*} \\
10^{-8} \mathrm{M} \mathrm{Cd}^{2+}\end{array}$ & {$[49]$} \\
\hline Inv Mu Gox & $\begin{array}{l}\text { Amperometry; } \mathrm{Pt} / \mathrm{Inv}-\mathrm{Mu}-\mathrm{Gox} \text {-laponite; }+0.6 \text { versus } \\
\mathrm{Ag} / \mathrm{AgCl}\end{array}$ & $3 \mathrm{ppb} \mathrm{Hg}^{2+}$ & {$[50]$} \\
\hline LDH LOD & $\begin{array}{l}\text { Amperometry; Clark electrode (Pt } \\
\text { cathode);-0.7 Vversus Ag/AgCl }\end{array}$ & $\begin{array}{l}1 \mu \mathrm{M} \mathrm{HgCl}_{2}, 10 \mu \mathrm{M} \mathrm{Cu}^{2+} \\
25 \mu \mathrm{M} \mathrm{Zn}^{2+}\end{array}$ & {$[22]$} \\
\hline NR & $\begin{array}{l}\text { Conductometry; Pt/NR-GA-BSA-metyl viologen/ } \\
\text { Nafion }\end{array}$ & $\begin{array}{l}0.05 \mu \mathrm{M} \mathrm{Cu}^{2+}, 0.5 \mu \mathrm{M} \\
\mathrm{Zn}^{2+}, 0.1 \mu \mathrm{M} \mathrm{Cd}^{2+}, 1 \mu \mathrm{M} \\
\mathrm{Pb}^{2+}\end{array}$ & {$[45]$} \\
\hline PQQ-GDH & $\begin{array}{l}\text { Amperometry; G/PQQ-GDH-GA; + } 0.25 \text { versus } \\
\mathrm{Ag} / \mathrm{AgCl}\end{array}$ & $\begin{array}{l}15^{*} 10^{-5} \mathrm{M} \mathrm{Cd}^{2+}, 15^{*} \\
10^{-5} \mathrm{M} \mathrm{Pb}^{2+}\end{array}$ & {$[15]$} \\
\hline Ty & Amperometry; GCE/Ty-pPy;+0.4 versus Ag/AgCl & $510^{-7} \mathrm{M} \mathrm{Cr}^{3+}$ & {$[41]$} \\
\hline Ty & Conductometry; Ty-GA-BSA/Pt;- & $1 \mathrm{ppb} \mathrm{Cu}{ }^{2+}$ & {$[40]$} \\
\hline Urease & Amperometry; Pt/PVF/urease;+0.7 V versus SCE & $7.4 \mu \mathrm{M} \mathrm{Hg}^{2+}$ & {$[34]$} \\
\hline Urease & Potentiometry; PVC- $\mathrm{NH}_{2} / \mathrm{Au}-\mathrm{NP} /$ urease;- & $0.05 \mu \mathrm{M} \mathrm{Hg}^{2+}$ & {$[53]$} \\
\hline Urease & Potentiometry;SPE $\left(\mathrm{RuO}_{2}+\right.$ urease + graphite $) ;-$ & - & {$[54]$} \\
\hline Urease & Potentiometry; $\mathrm{Ir} / \mathrm{IrO}_{2} /$ Urease-PVC;- & $0.02 \mu \mathrm{M} \mathrm{Hg}^{2+}$ & {$[5]$} \\
\hline Urease & Potentiometry; $\mathrm{NH}_{4}^{+}$- ENFET;- & $0.2 \mu \mathrm{M} \mathrm{Cu}^{2+}, 0.1 \mu \mathrm{M} \mathrm{Hg}^{2+}$ & {$[55]$} \\
\hline Urease & Conductometry; SPE;- & $\begin{array}{l}0.005 \mathrm{mM} \mathrm{Hg}^{2+}, 0.02 \mathrm{mM} \\
\mathrm{Cu}^{2+}, 0.1 \mathrm{mM} \mathrm{Cd}^{2+} \\
0.9 \mathrm{mM} \mathrm{Pb}^{2+}\end{array}$ & {$[35]$} \\
\hline Urease/GLDH & Amperometry; C-Rh; +0.3 versus $\mathrm{Ag} / \mathrm{AgCl}$ & $\begin{array}{l}7.2 \mu \mathrm{g} / \mathrm{L} \mathrm{Hg}^{2+}, 8.5 \mu \mathrm{g} / \mathrm{L} \\
\mathrm{Cu}^{2+}, 0.3 \mathrm{mg} / \mathrm{L} \mathrm{Cd}^{2+} \\
0.2 \mathrm{mg} / \mathrm{L} \mathrm{Zn}^{2+}\end{array}$ & {$[56]$} \\
\hline
\end{tabular}

$\mathrm{ALP}=$ alkaline phosphatase; $\mathrm{Au}-\mathrm{NP}=$ gold nanoparticles; $\mathrm{BSA}=$ bovine serum albumin; $\mathrm{C}-\mathrm{Rh}=$ rhodinised carbon electrode; ENFET $=$ enzyme field effect transistor; Fc = ferrocene; $\mathrm{MB}=$ methylene blue; $\mathrm{GA}=$ glutaraldehyde; $\mathrm{GdA}=$ glutaric dialdehyde; $\mathrm{GCE}=$ glassy carbon electrode; $\mathrm{GLDH}=$ glutamate dehydrogenase; $\mathrm{Gox}=$ glucose oxidase; Inv = invertase; $\mathrm{Mu}=$ mutarotase; $\mathrm{NR}=$ nitrate reductase; $\mathrm{PA}=$ polyaniline; $\mathrm{PPD}=$ poly $(o$-phenylenediamine $) ; \mathrm{pPy}=$ polypyrrole; $\mathrm{PQQ}-\mathrm{GDH}=$ pyrroloquinoline quinine dependent glucose dehydrogenase; $\mathrm{PVC}=$ poly(vinyl chloride); $\mathrm{PVC}-\mathrm{NH}_{2}=$ ethylenediamine poly $($ vinyl chloride); $\mathrm{PVF}=$ poly (vinylferrocenium); SCE = saturated calomel electrode; SPE = screen-printed electrode; Ty = tyrosinase. 
TABLE 5: Examples of DNA-based electrodes.

\begin{tabular}{|c|c|c|c|}
\hline Electrode & $\begin{array}{l}\text { Immobilisation } \\
\text { technique }\end{array}$ & Toxic effect & References \\
\hline GCE/ds-DNA & Deposition & $\begin{array}{l}\mathrm{Pb}^{2+} \text { interacts with ds-DNA } \\
\text { preferentially at adenine-containing } \\
\text { segments, leading to modifications } \\
\text { in the double-helical structure. }\end{array}$ & {$[58]$} \\
\hline SMFE/ss-DNA & $\begin{array}{c}\text { Inclusion in a CN } \\
\text { membrane }\end{array}$ & $\begin{array}{l}\mathrm{Pb}^{2+} \text { and } \mathrm{Cd}^{2+} \text { covalent bind during } \\
\text { complexation with ss-DNA. } \\
\text { Constants of binding (estimated } \\
\text { from Scatchard graphs): } K_{\text {bind }}\left(\mathrm{Pb}^{2+}\right. \\
- \text { ssDNA })=(12 \pm 0.3)^{*} 10^{5} \mathrm{M}^{-1} ; \\
K_{\text {bind }}\left(\mathrm{Fe}^{3+}-\mathrm{ssDNA}\right)=(1.4 \pm 0.3)^{*} \\
10^{5} \mathrm{M}^{-1} ; K_{\text {bind }}\left(\mathrm{Cd}^{2+}-\text { ssDNA }\right)= \\
(0.6 \pm 0.2)^{*} 10^{5} \mathrm{M}^{-1} \text {. Limits of } \\
\text { detection: } 10^{-10} \mathrm{M} \mathrm{Pb}^{2+}, 10^{-9} \mathrm{M} \\
\mathrm{Cd}^{2+} \text { and } 10^{-7} \mathrm{M} \mathrm{Fe}^{3} \text {. }\end{array}$ & {$[61]$} \\
\hline $\mathrm{Au} / \mathrm{ss}-\mathrm{DNA}$. & $\begin{array}{l}\text { Self assembled } \\
\text { method }\end{array}$ & $\begin{array}{l}\mathrm{Cd}^{2+} \text { has the ability to be deposited } \\
\text { at underpotential conditions onto } \\
\text { gold substrates when it is } \\
\text { electrochemically reduced. } \\
\text { Constant of binding } K_{\text {bind }} \\
\left(\mathrm{Cd}^{2+} \text {-ssDNA) }=8.33^{*} 10^{5} \mathrm{M}^{-1} \text {. }\right. \\
\text { Limit of detection: } 10 \mathrm{pM} \mathrm{Cd}^{2+} \text {. }\end{array}$ & {$[59]$} \\
\hline $\begin{array}{l}\text { SPE/ds-DNA and } \\
\text { SPE/MWCNT-ds- } \\
\text { DNA }\end{array}$ & Deposition on SPE & $\mathrm{Sn}^{2+}$ and $\mathrm{As}^{3+}$ was studied. & {$[62]$} \\
\hline
\end{tabular}

GCE = glassy carbon electrode; SMFE = stationary mercury-film electrode; $\mathrm{CN}=$ cellulose nitrate; $\mathrm{MWCNT}=$ multi-wall carbon nanotubes; $\mathrm{SPE}=$ screen printed electrode.

TABLE 6: Advantages and disadvantages of whole cell based biosensor.

\begin{tabular}{|c|c|}
\hline Advantages & Disadvantages \\
\hline (i) React only to the available fraction of metal ions; & (i) The limited understanding of the biochemistry involved. \\
\hline (ii) Are fast, less expensive, and less intensive labour; & (ii) Lack of genetic stability and short lifetime \\
\hline (iii) Are compatible with and comparable to chemical analysis; & $\begin{array}{l}\text { (iii) Cells require relatively long incubation time (usually longer } \\
\text { than } 30 \mathrm{~min} \text { ); }\end{array}$ \\
\hline (iv) Are more sensitive than chemical methods; & (iv) Difficult reversibility of the signal \\
\hline $\begin{array}{l}\text { (v) Produces real-time data and can be applied in field work or } \\
\text { in situ analysis; does not involve the bulky, fragile equipment, or } \\
\text { specialized training; }\end{array}$ & $\begin{array}{l}\text { (v) Experimental conditions (temperature, } \mathrm{pH} \text {, incubation time, } \\
\text { buffer, and reagents) can effects the luminescence production and } \\
\text { thus the biosensor performances }\end{array}$ \\
\hline $\begin{array}{l}\text { (vi) They are more tolerant of suboptimal } \mathrm{pH} \text { and temperatures } \\
\text { than purified enzymes; }\end{array}$ & (vi) Less/limited of selectivity \\
\hline \multicolumn{2}{|l|}{$\begin{array}{l}\text { (vii) Are cheaper to use because the active biological } \\
\text { component does not have be isolated and because } \\
\text { microorganisms are living, unlimited quantities can be } \\
\text { prepared relatively inexpensive; }\end{array}$} \\
\hline \multicolumn{2}{|l|}{$\begin{array}{l}\text { (viii) Can provide information about the bioavailability of the } \\
\text { analyte; }\end{array}$} \\
\hline $\begin{array}{l}\text { (xi) May perform multi-step reactions since all reactions are } \\
\text { conveniently packaged within the cell and thus, efficiently } \\
\text { carried out. }\end{array}$ & \\
\hline
\end{tabular}

electrochemical biosensors is the immobilization of the DNA or its components (such as nucleotides, nucleosides, purine, and pyrimidine bases) on the electrode surface. Different adsorption immobilization procedures, such as electrostatic adsorption or evaporation, adsorption of a monolayer, or multilayer DNA films have been widely used [58].
Because DNA has four different potential sites for binding of metal ions: (1) the negatively charged phosphate oxygen atoms, (2) the ribose hydroxyls, (3) the base ring nitrogens, and (4) the exocyclic base keto groups [58], in the case of DNA biosensors, there are two possibilities to detect pollutants: one is to detect the hybridization of nucleic 
TABLE 7: Examples of recombinant bacteria for specific heavy metal detection.

\begin{tabular}{|c|c|c|c|c|c|}
\hline \multicolumn{2}{|c|}{ Biorecognition element } & \multirow{2}{*}{$\begin{array}{l}\text { Metal ion/ } \\
\text { detection limit }\end{array}$} & \multirow{2}{*}{ Linear range } & \multirow{2}{*}{ Detection method } & \multirow{2}{*}{ References } \\
\hline $\begin{array}{l}\text { Promoter/ } \\
\text { reporter gene }\end{array}$ & Host microorganism & & & & \\
\hline (1) & $(2)$ & (3) & $(4)$ & $(6)$ & $(7)$ \\
\hline \multicolumn{6}{|c|}{ Bacteria } \\
\hline Ars pR773/lacZ & Escherichia coli & $\begin{array}{l}\mathrm{As}^{3+} / 50 \mu \mathrm{M} \\
\mathrm{Sb}^{3+} / 1 \mathrm{fM}\end{array}$ & $\mu \mathrm{M}-\mathrm{mM} ; \mathrm{fM}-\mu \mathrm{M}$ & Chemiluminescence & {$[73]$} \\
\hline CUP 1/lacZ & $\begin{array}{l}\text { Saccharomyces } \\
\text { cerevisiae }\end{array}$ & $\mathrm{Cu}^{2+}$ & $16.0-32.0 \mathrm{mg} / \mathrm{L}$ & $\begin{array}{c}\text { Amperometry/ - } 0.6 \mathrm{~V} \\
\text { versus } \mathrm{Ag} / \mathrm{AgCl}\end{array}$ & {$[80]$} \\
\hline $\begin{array}{l}\text { pMOL } 90+ \\
\text { Tn4431/luxCDABE }\end{array}$ & $\begin{array}{l}\text { Alcaligenes eutrophus } \\
\text { (AE1239) }\end{array}$ & $\mathrm{Cu}^{2+} / 1 \mu \mathrm{M}$ & $0-250 \mu \mathrm{M}$ & Bioluminescence & {$[81]$} \\
\hline $\begin{array}{l}\text { cadA and cad } \\
\mathrm{C} / l u c \mathrm{FF}\end{array}$ & $\begin{array}{c}\text { Staphylococcus aureus } \\
\text { (RN4220) }\end{array}$ & $\begin{array}{c}\mathrm{Cd}^{2+} / 10 \mathrm{nM} ; \\
\mathrm{Pb}^{2+} / 33 \mathrm{nM} ; \mathrm{Sb}^{2+} / 1 \\
\mathrm{nM}\end{array}$ & $\begin{array}{c}10 \mathrm{nM} 1 \mu \mathrm{M} \\
33 \mathrm{nM}-330 \mu \mathrm{M} \\
1 \mathrm{nM}-330 \mathrm{nM}\end{array}$ & Bioluminescence & {$[82]$} \\
\hline mer /lux & $\begin{array}{l}\text { Escherichia coli (CM } \\
\text { 2624) }\end{array}$ & $\mathrm{Hg}^{2+}$ & & Bioluminescence & {$[83]$} \\
\hline merR/luxFF & Escherichia coli (S30) & $\mathrm{Hg}^{2+}$ & & Luminescence & {$[84]$} \\
\hline merR/luxFF & $\begin{array}{c}\text { Escherichia coli (MC } \\
1061)\end{array}$ & $\mathrm{Hg}^{2+}$ & & Luminescence & {$[85]$} \\
\hline -/DsRed-GFP & $\begin{array}{c}\text { Escherichia coli } \\
(\mathrm{DH} 5 \alpha)\end{array}$ & $\mathrm{Cu}^{2+} / 45 \mathrm{nM}$ & & Fluorescence & {$[86]$} \\
\hline$-/$ lux & $\begin{array}{l}\text { Burkholderia sp } \\
\quad(\text { RASC c2) }\end{array}$ & $\begin{array}{l}\mathrm{Zn}^{2+} / 1.7 \mu \mathrm{g} / \mathrm{mL} \\
\mathrm{Cu}^{2+} / 0.09 \mu \mathrm{g} / \mathrm{mL}\end{array}$ & & Bioluminescence & {$[70]$} \\
\hline $\mathrm{cad} / r s-G F P$ & $\begin{array}{l}\text { Escherichia coli } \\
\quad(\mathrm{DH} 5 \alpha)\end{array}$ & $\begin{array}{l}\mathrm{Cd}^{2+} / 0.1 \mathrm{nmol} / \mathrm{L} ; \\
\mathrm{Pb}^{2+} / 10 \mathrm{nmol} / \mathrm{L} ; \\
\mathrm{Sb}^{3+} / 0.1 \mathrm{nmol} / \mathrm{L}\end{array}$ & & Fluorescence & {$[87]$} \\
\hline -/eGFP205C & $\begin{array}{c}\text { Escherichia coli }(\mathrm{K} 12) \\
\text { Caenorhabditis } \\
\text { elegans }\end{array}$ & $\mathrm{Hg}^{2+}$ & & Fluorescence & {$[88]$} \\
\hline copA/lux & $\begin{array}{c}\text { Escherichia coli } \\
\text { (W3110) }\end{array}$ & $\mathrm{Cu}^{2+}, \mathrm{Ag}^{+}, \mathrm{Au}^{3+}$ & & Bioluminescence & {$[89]$} \\
\hline \multicolumn{6}{|c|}{ Algae } \\
\hline Tetraselmis ch & uii (Prasinophyceae)/CPE & $\mathrm{Cu}^{2+} / 4.610^{-10} \mathrm{M}$ & $510^{-8}-10^{-6} \mathrm{M}$ & $\begin{array}{c}\text { Amperometry/ }-0.4 \mathrm{~V} \\
\text { versus } \mathrm{Ag} / \mathrm{AgCl}\end{array}$ & {$[90]$} \\
\hline & lorella vulgaris & $\mathrm{Cd}^{2+}$ & & $\begin{array}{l}\text { Synchronous-scan } \\
\text { Spectrofluorimetry }\end{array}$ & {$[91]$} \\
\hline AlkP fror & Chlorella vulgaris/Pt & $\mathrm{Cd}^{2+}, \mathrm{Zn}^{2+} / 10 \mathrm{ppb}$ & & Conductometry & {$[75]$} \\
\hline Phot & midium sp./CPE & $\mathrm{Pb}^{2+} / 2.510^{-8} \mathrm{M}$ & $510^{-8}-210^{-5} \mathrm{M}$ & CV, DPSV & {$[92]$} \\
\hline \multicolumn{6}{|c|}{ Yeast cell } \\
\hline Rhodotor & ula mucilaginosa/CPE & $\mathrm{Cu}^{2+}$ & $10^{-7}-10^{-5} \mathrm{M}$ & CV, DPSV & {$[93]$} \\
\hline \multicolumn{6}{|c|}{ Fungi } \\
\hline Rhizc & pus arrhizus/CPE & $\mathrm{Pb}^{2+} / 0.510^{-8} \mathrm{M}$ & $10^{-7}-1.2510^{-5} \mathrm{M}$ & CV, DPSV & {$[94]$} \\
\hline \multicolumn{6}{|c|}{ Metal-binding protein } \\
\hline Synthetic & phytochelatin (EC)/Au & 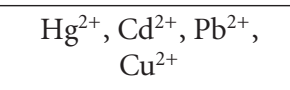 & $1 \mathrm{fM}-10 \mathrm{mM}$ & capacitance & {$[68]$} \\
\hline & ST-SmtA/Au & $\mathrm{Hg}^{2+}$ & & capacitance & {$[83]$} \\
\hline & ST-SmtA/Au & $\begin{array}{l}\mathrm{Hg}^{2+}, \mathrm{Cd}^{2+}, \mathrm{Cu}^{2+}, \\
\mathrm{Zn}^{2+} / 10^{-15} \mathrm{M}\end{array}$ & & capacitance & {$[6,95]$} \\
\hline & $\operatorname{MerR} / \mathrm{Au}$ & $\begin{array}{l}\mathrm{Hg}^{2+}, \mathrm{Cd}^{2+}, \mathrm{Cu}^{2+}, \\
\mathrm{Zn}^{2+} / 10^{-15} \mathrm{M}\end{array}$ & & capacitance & {$[6,95]$} \\
\hline Cytocrom 3 from $D$ & sulfomicrobium norvegicum/GCE & $\mathrm{Cr}^{6+} / 0.2 \mathrm{mg} / \mathrm{L}$ & & $\begin{array}{c}\text { Amperometry/-0,53 V } \\
\text { versus SCE }\end{array}$ & {$[96]$} \\
\hline
\end{tabular}


TABle 7: Continued.

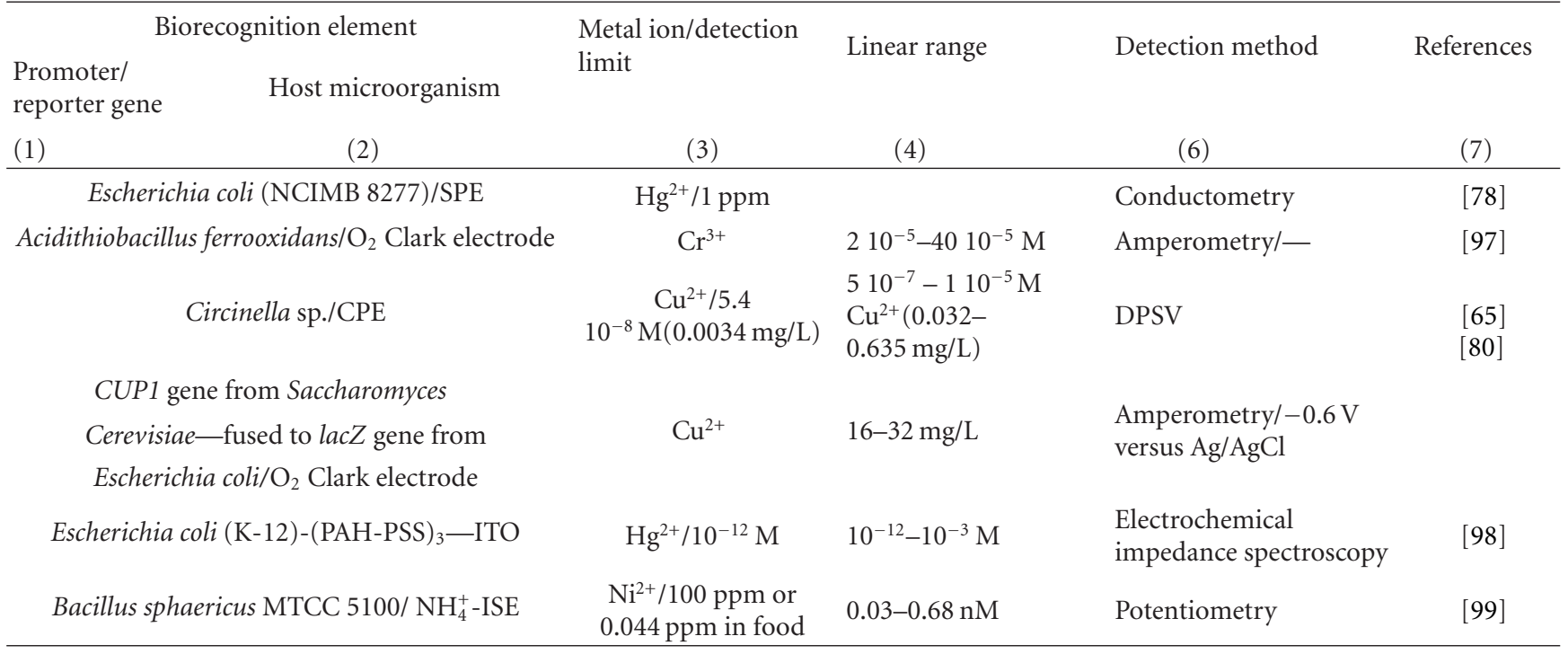

$\mathrm{CPE}=$ carbon paste electrode; $\mathrm{CV}=$ cyclic voltammetry, DPSV = differential pulse stripping voltammetry, GCE = glassy carbon electrode; ISE = ion selective electrode; ITO = indium-tin-oxide glass electode; lucFF = firefly luciferase; PAH = poly(allylamine hydrochlorure); PSS = poly (styrene sulfonate); $r s$-GFP = red-shifted green fluorescent protein; SCE = saturated calomel electrode, SPE = screen-printing electrode.

acid sequences from infectious microorganisms, and the other one is to monitor the interaction of small pollutants with the immobilized DNA (drugs, mutagenic pollutants, etc.) [39]. Most HM ions interact with more than two different sites and their interactions with DNA are more complex. Under chosen conditions, the following methods of metal-DNA interactions are proposed: (i) indirect chelation between the nitrogen $N_{7}$ atom of the DNA purine base with the oxygen atom of the DNA phosphate backbone and (ii) direct coordination bond with the nitrogen $N_{7}$ of guanine base (rarely of adenine). Two additional models have been identified: (a) intrastrand chelating between $N_{7}$ and $O_{6}$ atoms of guanine and (b) intrastrand bindings formation with the $N_{7}$ guanine atoms of ss-DNA $[58,59,61]$.

Several examples and the obtained results/conclusions are synthesised in Table 5 .

\section{Immunosensors}

This type of device attaches the recognition elements (antibody-antigen, $\mathrm{Ab}-\mathrm{Ag}$ ) with a physicochemical transduction element (electrochemical, optical, piezoelectric, and SPR) and generally presents the advantages of sensitivity and selectivity derived from the immunochemical interactions [63]. Important restrictions are the difficulties to regenerate the immune surface and cross-reactivity, while a certain degree of cross-reactivity is often desirable to detect different species of the same class [39].

Antibody-antigen interactions propose an alternative procedure for metal ion detection, based on the availability of antibodies to bind HMs. The KinExA 3000 is an example of an immunodevice based on the high surface area of beads containing an immobilized capture reagent (proteinthioureido-L-benzyl-chelate-metal) in the flow cell of an instrument. Since the immobilized antigen is in contact for a limited time with the antibody-binding sites, the KinExA is a device more sensitive, with a lower limit of detection, where the antibody binds with higher affinity to the immobilized antigen, than in the soluble case [64].

\section{Whole-Cell-Based Biosensors}

A whole cell-based biosensor is an analytical device which integrates whole cells-which are responsible for its selectivity-with a physical transducer to generate a measurable signal proportional to the concentration of analytes. These natural receptors, which can specifically bind HMs, are proteins of noncatalytic or nonimmunogenic origin [39] and microorganisms such as: bacteria, mosses, algae $[65,66]$, yeasts [67], fungi, and lichens $[6,68]$. By coupling the cells to a transducer that convert the cellular response into detectable signals it can be express the HM toxicity from a variety of environmental media including soil, sediment, and water $[39,69]$.

5.1. Bioluminescent-Based Sensor. It is well known that low concentrations of HMs $(0.01-0.05 \mu \mathrm{g} / \mathrm{mL})$ stimulated light output. This stimulation might occur due to (i) the modifications of the composition of fatty acid in cell membrane which affect the synthesis of fatty acids into intracellular media (and therefore alter the biochemical pathway of the light reaction) or to (ii) the interruption in the cell energy production [70]. As consequence, light production from the whole cell depends on the energy derived from the electron transport chain, so that luminescence measuring 


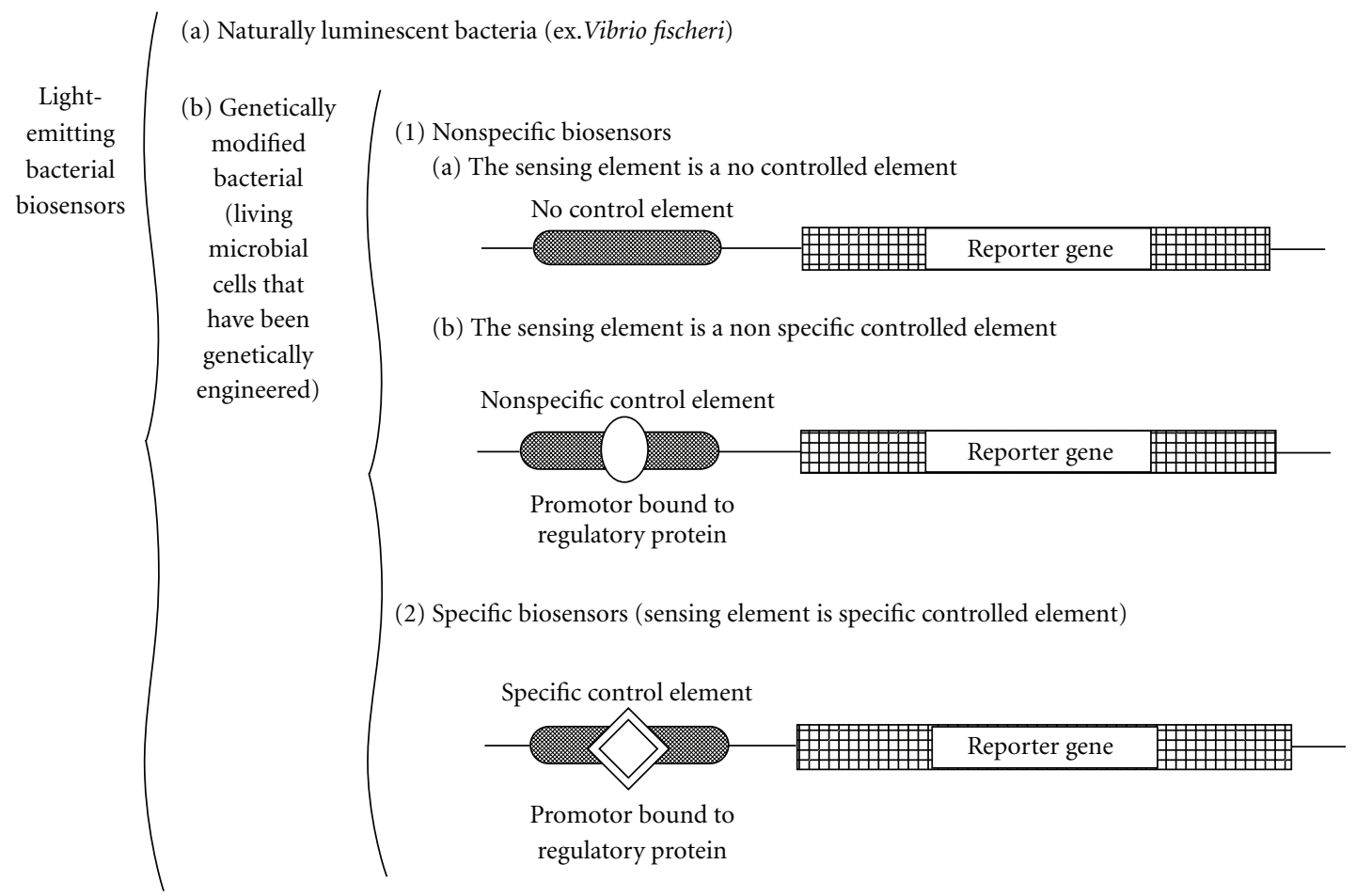

FIgURE 2: Classification of light-emitting bacterial biosensors.

gives information about the metabolic activity. According to the classical definition, the whole cell must be integrated with a transducer (photometer, luminometer, charged-couple device, and liquid-scintillation counter) to function as a true biosensor [67]. As consequence, the principle of biosensor based on bioluminescence is to estimate the toxicity of HMs by measuring the decrease in light output from the bacterium, when it is exposed to environmental samples [71].

The biosensors based on light-emitting bacteria could be classified in function of recognition element as described in Figure $2[39,67,69,72-74]$.

For surviving and growing in environments containing levels of toxic metals, the microorganisms have developed a variety of mechanisms, as following [73]:

(i) exclusion of the metal by the cell membrane;

(ii) active transport of the metal from the cell;

(iii) sequestration of the metal inside the cell, so that it is not able to produce its toxic effects;

(iv) sequestration of the metal in extracellular media, to prevent its entering into the cell;

(v) chemical transformation of the metal in a compound that is less toxic to the cell.

Certainly, biosensors based on bacterial whole cell have either advantages or disadvantages over conventional methods of detecting contaminants (Table 6) [67-69, 73].

Whole cells/microbial biosensors typically suffer from the poor selectivity because of the nonspecific cellular response to substrates. There are several ways to improve the selectivity of microbial biosensors: (i) using the biotechnology developments in the field of genetically engineering of cells with specific metabolic pathways upregulated or downregulated; (ii) to develop cell-based sensor arrays which generate a finger-printed response pattern; (iii) using the nanotechnology developments especially in the field of the nanostructured materials which can be coimmobilized with whole cells; (iv) the use of microfabrication, for example, micron-sized electrodes in view to develop single cell-based devices; (v) to build a lab-on-a-chip technique in which the integration of a cells onto a microfluidic chip can develop a biotic-microelectromechanical system; (vi) to develop a simple immobilization method to achieve a cells monolayer with very strong adhesion to a surface and without losing any of its biological function, in view to avoid the limits of the chemical methods (covalent binding and cross-linking) or the poor stability induced by physical methods (adsorption and entrapment).

5.2. Examples of Biosensors Based on Whole Cells for Heavy Metal Detection. Representative examples of biosensors based on whole cells are given in Table 7. As it can be seen, except the optical detection, the change of conductivity $[75,76]$ or of capacitance $[68,77]$ at an electrode/solution interface can supply information about conformational changes of the immobilised cells in the presence of HMs. A disposable setup (CellSense TM) is an example of a commercial system that allows up to 32 disposable biosensors to be monitored in a simultaneous manner; using such device a large number of measurements and replicates can be performed rapidly (30 min per assay) $[78,79]$. 
The essential drawbacks (slow response, low sensitivity, and poor selectivity) using whole cells as biosensing element limit the widespread importance of commercial biosensors on the market.

\section{Conclusions}

Using the main interdisciplinary works from the past decades, the present paper summarises the recent progress in the fabrication and application of biosensors for HMs detection, with an accent on the types of immobilization techniques and the different types of transducers used. The increasing number of published papers has revealed the use of biosensors based on enzymes, DNA, or whole cellsas an easy technique for detections, HMs is in continuous improvement in a wide range of areas and also in the environmental market. Particularly, although the DNA and whole-cell-based biosensors have demonstrated their efficacy in gene discovery and genomics research, in the HMs detection they are more laboratory oriented and engage expensive equipment. The synergism between biotechnology and microelectronics lead developing new opportunities to build "smart" biosensors, highly integrated systems, and test kits applied in the alarm monitoring of environmental pollution, by using as bioreceptor novel enzymes or enzyme sources having a necessary enzyme activity. They will be small in size and high in sensitivity. However, until such biosensor accomplish operational characteristics similar to the simple $\mathrm{pH}$ electrode (in terms of durability, selectivity, extended concentration range, and resistance to biofouling), they will probable continue to meet major barriers to extensive acceptance and to be applied for environmental monitoring.

For practical applications, at this time there is a strong need for a really integrated biosensor system that includes probes, samplers, detector as well as amplifier, and logic circuitry. Thus systems have great promise to present several advantages in size, performance, fabrication, analysis, and production cost. The small sizes of the probes (microliter to nanoliter) minimize sample requirement and diminish reagent and waste requirement. Highly integrated systems lead to a decrease in noise and an increase in signal, due to the enhanced efficiency of sample collection and the reduction of interfaces. The capacity of large-scale production using low-cost integrated circuit technology is, also, a significant benefit. The process of assemblage of various components is made by simple integration of some elements on a single chip.

All evolutions in micromachining and nanotechnology and all progresses concerning the selectivity and stability of recognition elements of "smart" sensors, of molecular devices, and of multiparameter sensor arrays are evident to have a main impact on pollution control. Further efforts should be done (i) to the development of new immobilization techniques (that enhance the stability of the biocomponent), (ii) to the design of new electrocatalysts (that facilitate the detection of pollutants), (iii) to address the fouling and degradation of electrochemical sensors during use, and (iv) to the introduction of multisensor systems for simultaneous monitoring of several priority contaminants.

\section{References}

[1] N. K. Srivastava and C. B. Majumder, "Novel biofiltration methods for the treatment of heavy metals from industrial wastewater," Journal of Hazardous Materials, vol. 151, no. 1, pp. 1-8, 2008.

[2] I. Oehme and S. Wolfbeis, "Optical sensors for determination of heavy metal ions," Mikrochimica Acta, vol. 126, no. 3-4, pp. 177-192, 1997.

[3] R. B. Thompson, B. P. Maliwal, V. L. Feliccia, C. A. Fierke, and $\mathrm{K}$. McCall, "Determination of picomolar concentrations of metal ions using fluorescence anisotropy: biosensing with a "reagentless" enzyme transducer," Analytical Chemistry, vol. 70, no. 22, pp. 4717-4723, 1998.

[4] R. B. Thompson, B. P. Maliwal, and C. A. Fierke, "Selectivity and sensitivity of fluorescence lifetime-based metal ion biosensing using a carbonic anhydrase transducer," Analytical Biochemistry, vol. 267, no. 1, pp. 185-195, 1999.

[5] T. K. Vel Krawczyk, M. Moszczyńska, and M. Trojanowicz, "Inhibitive determination of mercury and other metal ions by potentiometric urea biosensor," Biosensors and Bioelectronics, vol. 15, no. 11-12, pp. 681-691, 2000.

[6] I. Bontidean, C. Berggren, G. Johansson et al., "Detection of heavy metal ions at femtomolar levels using protein-based biosensors," Analytical Chemistry, vol. 70, no. 19, pp. 41624169, 1998.

[7] S. Han, M. Zhu, Z. Yuan, and X. Li, "A methylene blue-mediated enzyme electrode for the determination of trace mercury(II), mercury(I), methylmercury, and mercuryglutathione complex," Biosensors and Bioelectronics, vol. 16, no. 1-2, pp. 9-16, 2001.

[8] J. E. Pearson, A. Gill, and P. Vadgama, "Analytical aspects of biosensors," Annals of Clinical Biochemistry, vol. 37, no. 2, pp. $119-145,2000$.

[9] D. R. Thévenot, K. Toth, R. A. Durst, and G. S. Wilson, "Electrochemical biosensors: recommended definitions and classification," Biosensors and Bioelectronics, vol. 16, no. 1-2, pp. 121-131, 2001.

[10] M. N. Velasco-Garcia and T. Mottram, "Biosensor technology addressing agricultural problems," Biosystems Engineering, vol. 84, no. 1, pp. 1-12, 2003.

[11] G. L. Turdean, S. E. Stanca, and I. C. Popescu, Biosenzori Amperometrici. Teorie si Aplicatii, Presa Universitara Clujana, Cluj-Napoca, Romania, 2005.

[12] F. García Sánchez, A. Navas Díaz, M. C. Ramos Peinado, and C. Belledone, "Free and sol-gel immobilized alkaline phosphatase-based biosensor for the determination of pesticides and inorganic compounds," Analytica Chimica Acta, vol. 484, no. 1, pp. 45-51, 2003.

[13] A. L. Berezhetskyy, O. F. Sosovska, C. Durrieu, J. M. Chovelon, S. V. Dzyadevych, and C. Tran-Minh, "Alkaline phosphatase conductometric biosensor for heavy-metal ions determination," ITBM-RBM, vol. 29, no. 2-3, pp. 136-140, 2008.

[14] R. Koncki, K. Rudnicka, and L. Tymecki, "Flow injection system for potentiometric determination of alkaline phosphatase inhibitors," Analytica Chimica Acta, vol. 577, no. 1, pp. 134139, 2006.

[15] I. Lapenaite, B. Kurtinaitiene, L. Pliuskys et al., "Application of PQQ-GDH based polymeric layers in design of biosensors for 
detection of heavy metals," Materials Science (Medžiagotyra), vol. 9, no. 4, pp. 431-435, 2003.

[16] R. A. Copeland, Enzymes: A Practical Introduction to Structure, Mechanism and Data Analysis, Wiley-VCH, 2nd edition, 2000.

[17] G. A. Evtugyn, H. C. Budnikov, and E. B. Nikolskaya, "Sensitivity and selectivity of electrochemical enzyme sensors for inhibitor determination,” Talanta, vol. 46, no. 4, pp. 465-484, 1998.

[18] G. A. Evtugyn, H. C. Budnikov, and E. B. Nikolskaya, "Biosensors for the determination of environmental inhibitors of enzymes," Russian Chemical Reviews, vol. 68, no. 12, pp. 10411064, 1999.

[19] A. Amine, H. Mohammadi, I. Bourais, and G. Palleschi, "Enzyme inhibition-based biosensors for food safety and environmental monitoring," Biosensors and Bioelectronics, vol. 21, no. 8, pp. 1405-1423, 2006.

[20] C. Malitesta and M. R. Guascito, "Heavy metal determination by biosensors based on enzyme immobilised by electropolymerisation," Biosensors and Bioelectronics, vol. 20, no. 8, pp. 1643-1647, 2005.

[21] J. L. Gelpi, J. J. Avilés, M. Busquets et al., "A theoretical approach to the discrimination and characterization of the different classes of reversible inhibitors," Concepts in Biochemistry, vol. 70, no. 10, pp. 805-816, 1993.

[22] S. Fennouh, V. Casimiri, A. Geloso-Meyer, and C. Burstein, "Kinetic study of heavy metal salt effects on the activity of L-lactate dehydrogenase in solution or immobilized on an oxygen electrode," Biosensors and Bioelectronics, vol. 13, no. 78, pp. 903-909, 1998.

[23] M. Albareda-Sirvent, A. Merkoçi, and S. Alegret, "Pesticide determination in tap water and juice samples using disposable amperometric biosensors made using thick-film technology," Analytica Chimica Acta, vol. 442, no. 1, pp. 35-44, 2001.

[24] M. Albareda-Sirvent, A. Merkoçi, and S. Alegret, "Thickfilm biosensors for pesticides produced by screen-printing of graphite-epoxy composite and biocomposite pastes," Sensors and Actuators B, vol. 79, no. 1, pp. 48-57, 2001.

[25] E. V. Gogol, G. A. Evtugyn, J. L. Marty, H. C. Budnikov, and V. G. Winter, "Amperometric biosensors based on nafion coated screen-printed electrodes for the determination of cholinesterase inhibitors," Talanta, vol. 53, no. 2, pp. 379-389, 2000.

[26] F. N. Kok, F. Bozoglu, and V. Hasirci, "Construction of an acetylcholinesterase-choline oxidase biosensor for aldicarb determination," Biosensors and Bioelectronics, vol. 17, no. 6-7, pp. 531-539, 2002.

[27] E. Wilkins, M. Carter, J. Voss, and D. Ivnitski, "A quantitative determination of organophosphate pesticides in organic solvents," Electrochemistry Communications, vol. 2, no. 11, pp. 786-790, 2000.

[28] S. Zhang, H. Zhao, and R. John, "Development of a quantitative relationship between inhibition percentage and both incubation time and inhibitor concentration for inhibition biosensors: theoretical and practical considerations," Biosensors and Bioelectronics, vol. 16, no. 9, pp. 1119-1126, 2001.

[29] A. Guerrieri, L. Monaci, M. Quinto, and F. Palmisano, "A disposable amperometric biosensor for rapid screening of anticholinesterase activity in soil extracts," Analyst, vol. 127, no. 1, pp. 5-7, 2002.

[30] T. Neufeld, I. Eshkenazi, E. Cohen, and J. Rishpon, "A micro flow injection electrochemical biosensor for organophosphorus pesticides," Biosensors and Bioelectronics, vol. 15, no. 5-6, pp. 323-329, 2000.
[31] S. Zhang, H. Zhao, and R. John, "A theoretical model for immobilized enzyme inhibition biosensors," Electroanalysis, vol. 13, no. 18, pp. 1528-1534, 2001.

[32] B. Rozum and R. Koncki, "Application of monofluorophosphate/alkaline phosphatase system in flow injection analysis," Talanta, vol. 77, no. 2, pp. 507-513, 2008.

[33] R. Ilangovan, D. Daniel, A. Krastanov, C. Zachariah, and R. Elizabeth, "Enzyme based biosensor for heavy metal ions determination," Biotechnology and Biotechnological Equipment, vol. 20, no. 1, pp. 184-189, 2006.

[34] F. Kuralay, H. Özyörük, and A. Yildiz, "Inhibitive determination of $\mathrm{Hg}^{2+}$ ion by an amperometric urea biosensor using poly(vinylferrocenium) film," Enzyme and Microbial Technology, vol. 40, no. 5, pp. 1156-1159, 2007.

[35] S. M. Lee and W. Y. Lee, "Determination of heavy metal ions using conductometric biosensor based on sol-gelimmobilized urease," Bulletin of the Korean Chemical Society, vol. 23, no. 8, pp. 1169-1172, 2002.

[36] N. J. Nepomuscene, D. Daniel, and A. Krastanov, "Biosensor to detect chromium in wastewater," Biotechnology and Biotechnological Equipment, vol. 21, no. 3, pp. 377-381, 2007.

[37] M. Singh, N. Verma, A. K. Garg, and N. Redhu, "Urea biosensors," Sensors and Actuators B, vol. 134, no. 1, pp. 345$351,2008$.

[38] G. A. Zhylyak, S. V. Dzyadevich, Y. I. Korpan, A. P. Soldatkin, and A. V. El'skaya, "Application of urease conductometric biosensor for heavy-metal ion determination," Sensors and Actuators B, vol. 24, no. 1-3, pp. 145-148, 1995.

[39] S. Rodriguez-Mozaz, M. P. Marco, M. J. Lopez De Alda, and D. Barceló, "Biosensors for environmental applications: future development trends," Pure and Applied Chemistry, vol. 76, no. 4, pp. 723-752, 2004.

[40] T. M. Anh, S. V. Dzyadevych, N. Prieur et al., "Detection of toxic compounds in real water samples using a conductometric tyrosinase biosensor," Materials Science and Engineering $C$, vol. 26, no. 2-3, pp. 453-456, 2006.

[41] O. Domínguez Renedo, M. A. Alonso Lomillo, and M. J. Arcos Martinez, "Optimisation procedure for the inhibitive determination of chromium(III) using an amperometric tyrosinase biosensor," Analytica Chimica Acta, vol. 521, no. 2, pp. 215-221, 2004.

[42] R. Solná, S. Sapelnikova, P. Skládal et al., "Multienzyme electrochemical array sensor for determination of phenols and pesticides," Talanta, vol. 65, no. 2, pp. 349-357, 2005.

[43] M. Stoytcheva and V. Sharkova, "Kinetics of the inhibition of immobilized acetylcholinesterase with $\mathrm{Hg}$ (II)," Electroanalysis, vol. 14, no. 14, pp. 1007-1010, 2002.

[44] A. M. Aiken, B. M. Peyton, W. A. Apel, and J. N. Petersen, "Heavy metal-induced inhibition of aspergillus niger nitrate reductase: applications for rapid contaminant detection in aqueous samples," Analytica Chimica Acta, vol. 480, no. 1, pp. 131-142, 2003.

[45] X. J. Wang, S. Q. Xia, J. F. Zhao, H. N. Zhao, and N. Renault Jaffrezic, "Inhibitive determination of heavy metal ions by conductometric nitrate reductase biosensor," Chemical Research in Chinese Universities, vol. 25, no. 4, pp. 443-445, 2009.

[46] I. Lapenaite, B. Kurtinaitiene, J. Razumiene et al., "Properties and analytical application of PQQ-dependent glycerol dehydrogenase from Gluconobacter sp. 33," Analytica Chimica Acta, vol. 549, no. 1-2, pp. 140-150, 2005.

[47] M. R. Guascito, C. Malitesta, E. Mazzotta, and A. Turco, "Inhibitive determination of metal ions by an amperometric glucose oxidase biosensor: study of the effect of hydrogen 
peroxide decomposition," Sensors and Actuators B, vol. 131, no. 2, pp. 394-402, 2008.

[48] J. X. Liu, X. M. Xu, L. Tang, and G. M. Zeng, "Determination of trace mercury in compost extract by inhibition based glucose oxidase biosensor," Transactions of Nonferrous Metals Society of China (English Edition), vol. 19, no. 1, pp. 235-240, 2009.

[49] D. Bagal-Kestwal, M. S. Karve, B. Kakade, and V. K. Pillai, "Invertase inhibition based electrochemical sensor for the detection of heavy metal ions in aqueous system: application of ultra-microelectrode to enhance sucrose biosensor's sensitivity," Biosensors and Bioelectronics, vol. 24, no. 4, pp. 657664, 2008.

[50] H. Mohammadi, A. Amine, S. Cosnier, and C. Mousty, "Mercury-enzyme inhibition assays with an amperometric sucrose biosensor based on a trienzymatic-clay matrix," Analytica Chimica Acta, vol. 543, no. 1-2, pp. 143-149, 2005.

[51] L. K. Shyuan, L. Y. Heng, M. Ahmad, S. A. Aziz, and Z. Ishak, "Evaluation of pesticide and heavy metal toxicity using immobilized enzyme alkaline phosphatase with an electrochemical biosensor," Asian Journal of Biochemistry, vol. 3, no. 6, pp. 359-365, 2008.

[52] S. D. Kamtekar, R. Pande, M. S. Ayyagari et al., "Trace analysis of $\mathrm{Zn}(\mathrm{II}), \mathrm{Be}(\mathrm{II})$, and $\mathrm{Bi}(\mathrm{III})$ by enzyme-catalyzed chemiluminescence," Analytical Chemistry, vol. 68, no. 1, pp. 216-220, 1996.

[53] Y. Yang, Z. Wang, M. Yang et al., "Inhibitive determination of mercury ion using a renewable urea biosensor based on selfassembled gold nanoparticles," Sensors and Actuators B, vol. 114, no. 1, pp. 1-8, 2006.

[54] D. Ogonczyk, L. Tymecki, I. Wyzkiewicz, R. Koncki, and S. Glab, "Screen-printed disposable urease-based biosensors for inhibitive detection of heavy metal ions," Sensors and Actuators B, vol. 106, no. 1, pp. 450-454, 2005.

[55] A. Senillou, N. Jaffrezic-Renault, C. Martelet, and S. Cosnier, "A miniaturized urea sensor based on the integration of both ammonium based urea enzyme field effect transistor and a reference field effect transistor in a single chip," Talanta, vol. 50, no. 1, pp. 219-226, 1999.

[56] B. B. Rodriguez, J. A. Bolbot, and I. E. Tothill, "Development of urease and glutamic dehydrogenase amperometric assay for heavy metals screening in polluted samples," Biosensors and Bioelectronics, vol. 19, no. 10, pp. 1157-1167, 2004.

[57] A. M. Tencaliec, S. Laschi, V. Magearu, and M. Mascini, "A comparison study between a disposable electrochemical DNA biosensor and a Vibrio fischeri-based luminescent sensor for the detection of toxicants in water samples," Talanta, vol. 69, no. 2, pp. 365-369, 2006.

[58] S. C. B. Oliveira, O. Corduneanu, and A. M. Oliveira-Brett, "In situ evaluation of heavy metal-DNA interactions using an electrochemical DNA biosensor," Bioelectrochemistry, vol. 72, no. 1, pp. 53-58, 2008.

[59] E. L. S. Wong, E. Chow, and J. J. Gooding, "The electrochemical detection of cadmium using surface-immobilized DNA," Electrochemistry Communications, vol. 9, no. 4, pp. 845-849, 2007.

[60] S. S. Babkina, N. A. Ulakhovich, and Y. I. Zyavkina, "Amperometric DNA biosensor for the determination of auto-antibodies using DNA interaction with Pt(II) complex," Analytica Chimica Acta, vol. 502, no. 1, pp. 23-30, 2004.

[61] S. S. Babkina and N. A. Ulakhovich, "Amperometric biosensor based on denatured DNA for the study of heavy metals complexing with DNA and their determination in biological, water and food samples," Bioelectrochemistry, vol. 63, no. 1-2, pp. 261-265, 2004.

[62] A. Ferancová, M. Adamovski, P. Gründler et al., "Interaction of tin(II) and arsenic(III) with DNA at the nanostructure film modified electrodes," Bioelectrochemistry, vol. 71, no. 1, pp. 33-37, 2007.

[63] M. Farré, L. Kantiani, S. Pérez, and D. Barceló, "Sensors and biosensors in support of EU Directives," Trends in Analytical Chemistry, vol. 28, no. 2, pp. 170-185, 2009.

[64] D. A. Blake, R. M. Jones, R. C. Blake, A. R. Pavlov, I. A. Darwish, and H. Yu, "Antibody-based sensors for heavy metal ions," Biosensors and Bioelectronics, vol. 16, no. 9-12, pp. 799809, 2001.

[65] Ş. Alpat, S. K. Alpat, B. H. Çadirci, I. Yaşa, and A. Telefoncu, "A novel microbial biosensor based on Circinella sp. modified carbon paste electrode and its voltammetric application," Sensors and Actuators B, vol. 134, no. 1, pp. 175-181, 2008.

[66] L. E. De-Bashan and Y. Bashan, "Immobilized microalgae for removing pollutants: review of practical aspects," Bioresource Technology, vol. 101, no. 6, pp. 1611-1627, 2010.

[67] J. Castillo, S. Gáspár, S. Leth et al., "Biosensors for life quality-design, development and applications," Sensors and Actuators B, vol. 102, no. 2, pp. 179-194, 2004.

[68] I. Bontidean, J. Ahlqvist, A. Mulchandani et al., "Novel synthetic phytochelatin-based capacitive biosensor for heavy metal ion detection," Biosensors and Bioelectronics, vol. 18, no. 5-6, pp. 547-553, 2003.

[69] H. Strosnider, Whole-cell bacterial biosensors and the detection of bioavailable arsenic, Ph.D. thesis, National Network of Environmental Management Studies, August 2003.

[70] F. A. Chinalia, G. I. Paton, and K. S. Killham, "Physiological and toxicological characterization of an engineered whole-cell biosensor," Bioresource Technology, vol. 99, no. 4, pp. 714-721, 2008.

[71] J. J. C. Dawson, C. D. Campbell, W. Towers, C. M. Cameron, and G. I. Paton, "Linking biosensor responses to $\mathrm{Cd}, \mathrm{Cu}$ and Zn partitioning in soils," Environmental Pollution, vol. 142, no. 3, pp. 493-500, 2006.

[72] J. Bhattacharyya, D. Read, S. Amos, S. Dooley, K. Killham, and G. I. Paton, "Biosensor-based diagnostics of contaminated groundwater: assessment and remediation strategy," Environmental Pollution, vol. 134, no. 3, pp. 485-492, 2005.

[73] S. Ramanathan, M. Ensor, and S. Daunert, "Bacterial biosensors for monitoring toxic metals," Trends in Biotechnology, vol. 15, no. 12, pp. 500-506, 1997.

[74] S. Ripp and G. S. Sayl, "Advanced bioreporter technologies for targeted sensing of chemical and biological agents," http://www.ceb.utk.edu.

[75] C. Chouteau, S. Dzyadevych, C. Durrieu, and J. M. Chovelon, "A bi-enzymatic whole cell conductometric biosensor for heavy metal ions and pesticides detection in water samples," Biosensors and Bioelectronics, vol. 21, no. 2, pp. 273-281, 2005.

[76] N. Jaffrezic-Renault and S. V. Dzyadevych, "Conductometric microbiosensors for environmental monitoring," Sensors, vol. 8, no. 4, pp. 2569-2588, 2008.

[77] C. Berggren, B. Bjarnason, and G. Johansson, "Capacitive biosensors," Electroanalysis, vol. 13, no. 3, pp. 173-180, 2001.

[78] R. Bhatia, J. W. Dilleen, A. L. Atkinson, and D. M. Rawson, "Combined physico-chemical and biological sensing in environmental monitoring," Biosensors and Bioelectronics, vol. 18, no. 5-6, pp. 667-674, 2003.

[79] H. Wang, X. J. Wang, J. F. Zhao, and L. Chen, "Toxicity assessment of heavy metals and organic compounds using 
CellSense biosensor with E. coli," Chinese Chemical Letters, vol. 19, no. 2, pp. 211-214, 2008.

[80] K. Tag, K. Riedel, H. J. Bauer, G. Hanke, K. H. R. Baronian, and G. Kunze, "Amperometric detection of $\mathrm{Cu}^{2+}$ by yeast biosensors using flow injection analysis (FIA)," Sensors and Actuators B, vol. 122, no. 2, pp. 403-409, 2007.

[81] S. Leth, S. Maltoni, R. Simkus et al., "Engineered bacteria based biosensors for monitoring bioavailable heavy metals," Electroanalysis, vol. 14, no. 1, pp. 35-42, 2002.

[82] S. Tauriainen, M. Karp, W. Chang, and M. Virta, "Luminescent bacterial sensor for cadmium and lead," Biosensors and Bioelectronics, vol. 13, no. 9, pp. 931-938, 1998.

[83] I. Bontidean, A. Mortari, S. Leth et al., "Biosensors for detection of mercury in contaminated soils," Environmental Pollution, vol. 131, no. 2, pp. 255-262, 2004.

[84] T. Pellinen, T. Huovinen, and M. Karp, "A cell-free biosensor for the detection of transcriptional inducers using firefly luciferase as a reporter," Analytical Biochemistry, vol. 330, no. 1, pp. 52-57, 2004.

[85] P. R. G. Barrocas, W. M. Landing, and J. M. Hudson, "Assessment of mercury(II) bioavailability using a bioluminescent bacterial biosensor: practical and theoretical challenges," Journal of Environmental Sciences, vol. 22, no. 8, pp. 1137$1143,2010$.

[86] J. P. Sumner, N. M. Westerberg, A. K. Stoddard et al., "DsRed as a highly sensitive, selective, and reversible fluorescencebased biosensor for both $\mathrm{Cu}^{+}$and $\mathrm{Cu}^{2+}$ ions," Biosensors and Bioelectronics, vol. 21, no. 7, pp. 1302-1308, 2006.

[87] V. H. C. Liao, M. T. Chien, Y. Y. Tseng, and K. L. Ou, "Assessment of heavy metal bioavailability in contaminated sediments and soils using green fluorescent protein-based bacterial biosensors," Environmental Pollution, vol. 142, no. 1, pp. 17-23, 2006.

[88] R. R. Chapleau and M. Sagermann, "Real-time in vivo imaging of mercury uptake in Caenorhabditis elegans through the foodchain," Toxicology, vol. 261, no. 3, pp. 136-142, 2009.

[89] J. V. Stoyanov, D. Magnani, and M. Solioz, "Measurement of cytoplasmic copper, silver, and gold with a lux biosensor shows copper and silver, but not gold, efflux by the CopA ATPase of Escherichia coli," FEBS Letters, vol. 546, no. 2-3, pp. 391-394, 2003.

[90] S. K. Alpat, Ş. Alpat, B. Kutlu, Ö. Özbayrak, and H. B. Büyükişik, "Development of biosorption-based algal biosensor for $\mathrm{Cu}(\mathrm{II})$ using Tetraselmis chuii," Sensors and Actuators $B$, vol. 128, no. 1, pp. 273-278, 2007.

[91] H. Nguyen-Ngoc, C. Durrieu, and C. Tran-Minh, "Synchronous-scan fluorescence of algal cells for toxicity assessment of heavy metals and herbicides," Ecotoxicology and Environmental Safety, vol. 72, no. 2, pp. 316-320, 2009.

[92] M. Yüce, H. Nazir, and G. Dönmez, "An advanced investigation on a new algal sensor determining $\mathrm{Pb}(\mathrm{II})$ ions from aqueous media," Biosensors and Bioelectronics, vol. 26, no. 2, pp. 321-326, 2010.

[93] M. Yüce, H. Nazir, and G. Dönmez, "A voltammetric Rhodotorula mucilaginosa modified microbial biosensor for $\mathrm{Cu}$ (II) determination," Bioelectrochemistry, vol. 79, no. 1, pp. 66-70, 2010.

[94] M. Yüce, H. Nazir, and G. Dönmez, "Using of Rhizopus arrhizus as a sensor modifying component for determination of $\mathrm{Pb}(\mathrm{II})$ in aqueous media by voltammetry," Bioresource Technology, vol. 101, no. 19, pp. 7551-7555, 2010.

[95] I. Bontidean, J. R. Lloyd, J. L. Hobman et al., "Bacterial metal-resistance proteins and their use in biosensors for the detection of bioavailable heavy metals," Journal of Inorganic Biochemistry, vol. 79, no. 1-4, pp. 225-229, 2000.

[96] C. Michel, A. Ouerd, F. Battaglia-Brunet et al., " $\mathrm{Cr}(\mathrm{VI})$ quantification using an amperometric enzyme-based sensor: interference and physical and chemical factors controlling the biosensor response in ground waters," Biosensors and Bioelectronics, vol. 22, no. 2, pp. 285-290, 2006.

[97] R. Zlatev, J. P. Magnin, P. Ozil, and M. Stoytcheva, "Bacterial sensors based on Acidithiobacillus ferrooxidans: part II. Cr(VI) determination," Biosensors and Bioelectronics, vol. 21, no. 8, pp. 1501-1506, 2006.

[98] M. Souiri, I. Gammoudia, H. Ben Ouada et al., "Escherichia coli-functionalized magnetic nanobeads as an ultrasensitive biosensor for heavy metals," Procedia Chemistry, vol. 1, no. 1, pp. 1027-1030, 2009.

[99] N. Verma and M. Singh, "A Bacillus sphaericus based biosensor for monitoring nickel ions in industrial effluents and foods," Journal of Automated Methods and Management in Chemistry, vol. 2006, Article ID 83427, pp. 1-4, 2006. 


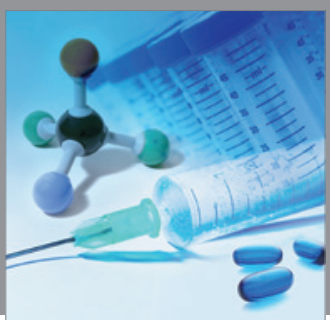

International Journal of

Medicinal Chemistry

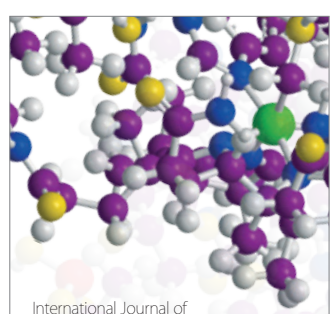

Carbohydrate Chemistry

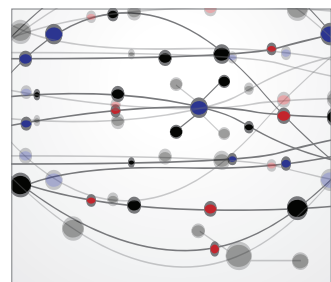

The Scientific World Journal
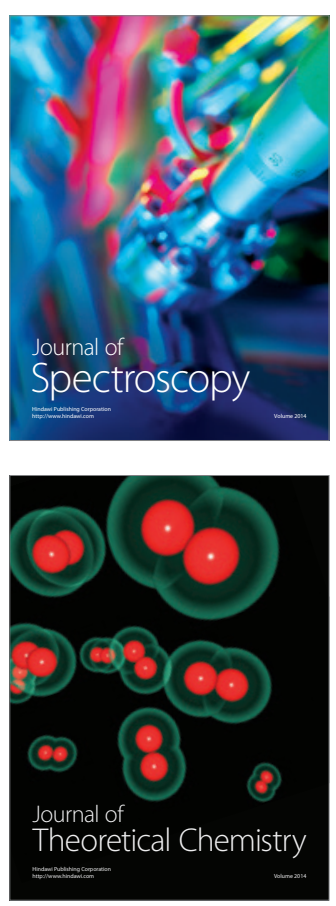
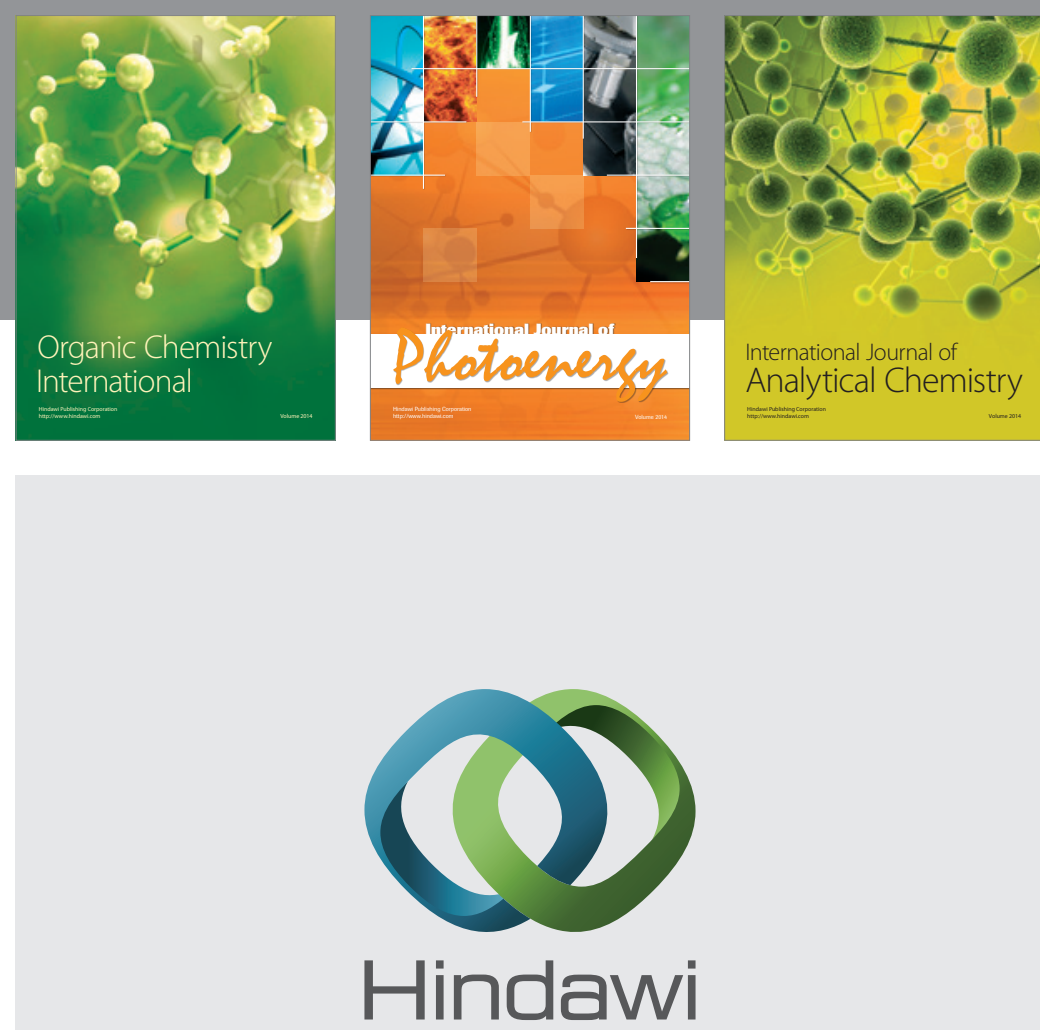

Submit your manuscripts at

http://www.hindawi.com
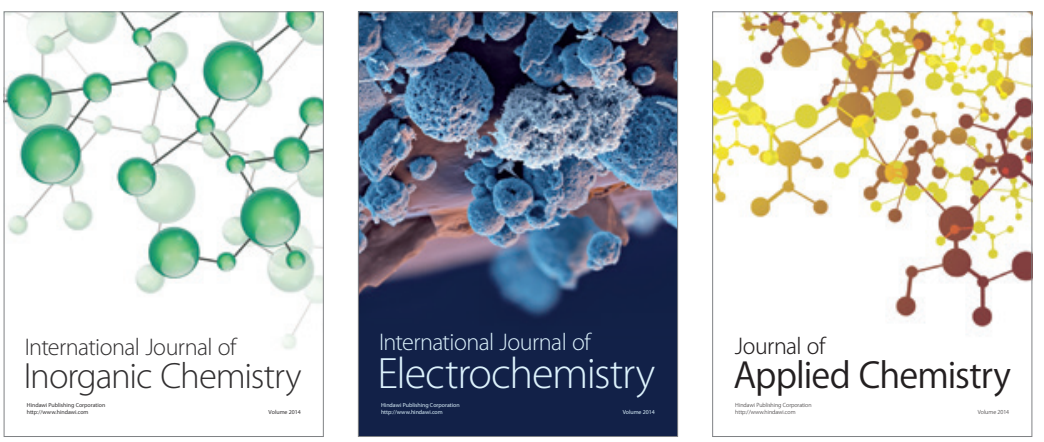

Journal of

Applied Chemistry
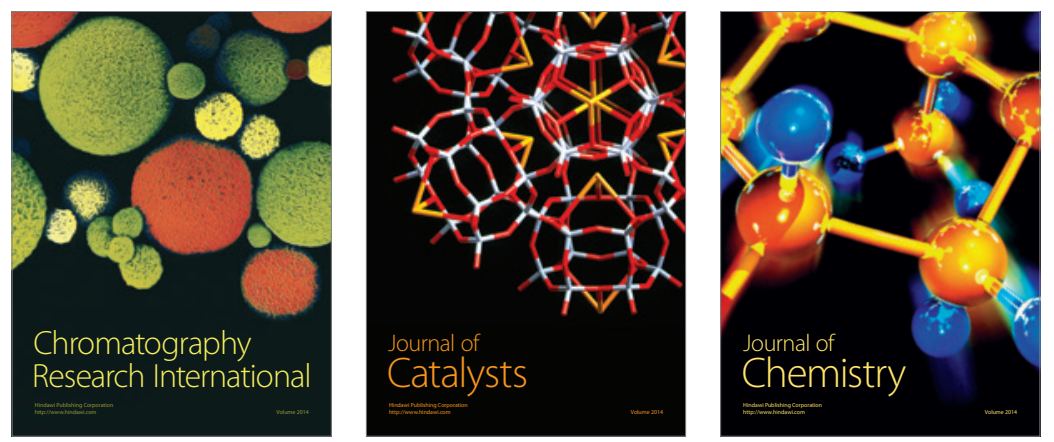
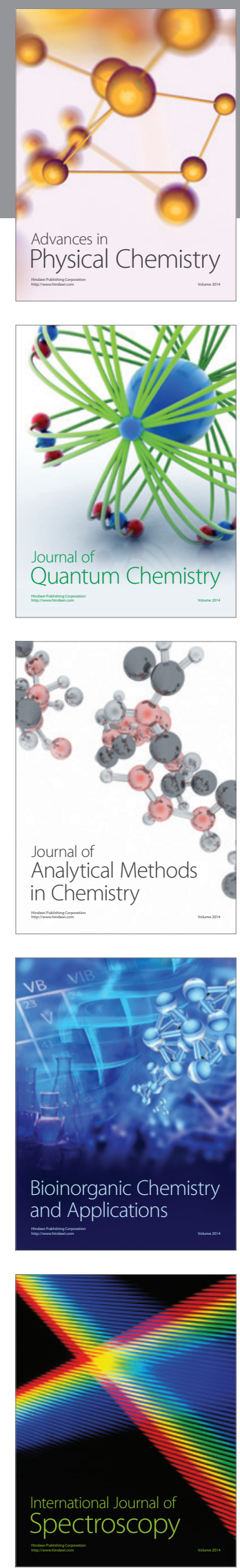